\title{
Collateral Attack and the Role of Adequate Representation in Class Suits for Money Damages
}

\author{
Patrick Woolley*
}

\section{INTRODUCTION}

Over the last decade, debate has raged over whether an absent class member may attack a class judgment for inadequate representation in subsequent litigation. ${ }^{1}$ The traditional understanding - dating back as far as Hansberry v. Lee $e^{2}$ - has been that an absent class member who has been inadequately represented has the right to collaterally attack a class judgment. ${ }^{3}$ As Federal Practice and Procedure has noted, a decision

* Beck, Redden \& Secrest Professor in Law, The University of Texas School of Law. I thank Stephen Clarke, Jordan Harrison, and Mark Tindall for their invaluable research assistance. Bob Bone, Lonny Hoffman, Jay Tidmarsh, and Rhonda Wasserman provided very helpful comments on an earlier draft. I also greatly profited from comments I received at the Kansas Law Review's symposium in October 2009 and at a Boalt Law School student-faculty workshop in April 2008 where I presented an early sketch of this Article at the invitation of Stephen Bundy and Eleanor Swift.

1. For a thoughtful and relatively even-handed accounting of the debate, see William B. Rubenstein, Finality in Class Action Litigation: Lessons From Habeas, 82 N.Y.U. L. REV. 790, 820 41 (2007).

2. 311 U.S. 32 (1940).

3. See 18A Charles Alan Wright et al., Federal Practice and Procedure $\S 4455$, at 485 (2002); ("It has long been the general understanding that only adequate representation can justify preclusion against nonparticipating class members."); id. at 487 (arguing that "[t]he traditional view" permitting collateral attack "should not be allowed to pass easily into the discarded heap of nice-but-antique procedures that are too wearisome to be endured in the press of modern needs"); Patrick Woolley, The Availability of Collateral Attack for Inadequate Representation in Class Suits, 79 TeX. L. REv. 383, 384-85, nn.2-3 (2001) (collecting extensive case law and legal scholarship). See also Matsushita Elec. Indus. Co. v. Epstein, 516 U.S. 367, 395-99 (1996) (Ginsburg, J., dissenting in part and concurring in part) (recognizing that "[f]inal judgments ... remain vulnerable to collateral attack for failure to satisfy the adequate representation requirement"). Numerous scholars have defended the traditional view over the last decade. See, e.g., Debra Lyn Bassett, Constructing Class Action Reality, 2006 BYU L. REV. 1415, 1453 (arguing that efforts to "reconstruct class action reality" by limiting collateral attacks on class judgments would "undermine the importance of the class action's representative nature"); Lonny S. Hoffman, Intersections of State and Federal Power: State Judges, Federal Law, and the "Reliance Principle," 81 TuL. L. Rev. 283, 326-27 (2007) (noting the importance of broad collateral review and stating that "[t]he traditional rule - and the one accepted by most courts and commentators - is that due process challenges to a prior judgment may be asserted collaterally when enforcement of the judgment is subsequently sought"); Susan P. Koniak, How Like a Winter? The Plight of Absent Class Members Denied Adequate Representation, 79 NOTRE DAME L. REV. 1787, 1836-61 (2004) (vigorously 
upholding the availability of collateral attack "seemed surprising only by taking such great effort to reach conclusions that many students would have thought clearly required by long tradition." ${ }^{4}$ But beginning with an influential article criticizing that decision, ${ }^{5}$ academic critics of collateral attack have mounted a serious and sustained effort to change the law. ${ }^{6}$

That effort - which has found support in some judicial opinions over the last decade 7 - has culminated in the Principles of the Law of

defending the traditional rule); Graham C. Lilly, Modeling Class Actions: The Representative Suit as an Analytical Tool, 81 NEB. L. REV. 1008, 1037 (2003) ("[T]he basic constitutional principle has been to permit unnamed class members to challenge the adequacy of their representation in a collateral trial."); see also David A. Dana, Adequacy of Representation After Stephenson: A Rawlsian/Behavioral Economics Approach to Class Action Settlements, 55 EMORY L.J. 279, 282 (2006) (arguing that a "rule allowing subsequent challenges to class action settlements is compelled by our basic intuitions of fairness and justice when class members could not conceivably have agreed to the arrangement had they been present but not known their precise position in the class").

4. WRIGHT ET AL., supra note 3, at 485. The treatise referred to the decision in Epstein v. MCA, Inc., 126 F.3d 1235 (9th Cir. 1997), a decision that was later vacated.

5. Marcel Kahan \& Linda Silberman, The Inadequate Search for "Adequacy" in Class Actions: A Critique of Epstein v. MCA, Inc., 73 N.Y.U. L. REV. 765 (1998) [hereinafter Kahan \& Silberman, The Inadequate Search]. See also Marcel Kahan \& Linda Silberman, Matsushita and Beyond: The Role of State Courts in Class Actions Involving Exclusive Federal Claims, 1996 SuP. CT. REV. 219, 277 (1996) [hereinafter Kahan \& Silberman, Matsushita] (contending that the argument that absent class members "are free to relitigate the issue of adequate representation and fairness of the settlement in their own action claims too much") (punctuation modified); Note, Collateral Attack on the Binding Effect of Class Action Judgments, 87 HARV. L. REV. 589, 603-04 (1974) (recommending that judicial findings of adequacy in the course of class proceedings be given preclusive effect).

6. See, e.g., Samuel Issacharoff \& Richard A. Nagareda, Class Settlements Under Attack, 156 U. PA. L. REV. 1649 (2008); Richard A. Nagareda, Administering Adequacy in Class Representation, 82 TEX. L. REV. 287, 379 (2004) (arguing that the law should "reject the expansive avenues for collateral attack upon class judgments that some commentators understandably have drawn from the ill-chosen rhetoric in Shutts") [hereinafter Nagareda, Administering Adequacy]; Woolley, supra note 3, at 387 n. 13 (collecting authority); see also Kevin R. Bernier, Note, The Inadequacy of the Broad Collateral Attack: Stephenson v. Dow Chemical Company and Its Effect on Class Action Settlements, 84 B.U. L. REv. 1023 (2003); Sara Maurer, Note, Dow Chemical Co. v. Stephenson: Class Action Catch 22, 55 S.C. L. REV. 467 (2004) (rejecting the Stephenson approach); Gregory M. Wirt, Comment, Missed Opportunity: Stephenson v. Dow Chemical Co. and the Finality of Class Action Settlements, 109 PENN St. L. ReV. 1297, 1313 (2005) ("[T]he Court should limit challenges to a class action settlement to a review of the procedures utilized during the settlement."). Some courts took a restrictive approach to collateral attack even before scholarly criticism mounted. See Woolley, supra note 3, at 385-86 nn.4-9 (collecting cases).

7. Courts that have addressed collateral attack over the last decade have been split. See, e.g., Pelt v. Utah, 539 F.3d 1271, 1284-89 (10th Cir. 2008) (stating that collateral attack is appropriate with respect to class judgments in Rule 23(b)(1) and 23(b)(2) suits, while acknowledging that an earlier Tenth Circuit case held that due process requires notice rather than adequate representation in Rule 23(b)(3) suits); Wolfert v. Transamerica Home First, Inc., 439 F.3d 165, 170-72 (2d Cir. 2006) (prohibiting collateral attack if the alleged inadequacy was addressed by the class court); In re Diet Drugs Prods. Liab. Litig., 431 F.3d 141, 145-46 (3d Cir. 2005) (relying on circuit precedent to reject collateral attack); Stephenson v. Dow Chem. Co., 273 F.3d 249, 257-61 (2d Cir. 2001) (authorizing collateral attack); Janik v. Rudy, 119 Cal. App. 4th 930, 944 n.3 (Cal. Ct. App. 2004) (recognizing that at a minimum collateral attack is permissible when the class court did not address the basis for the adequacy objection); Aguirre v. Albertson's, Inc., 117 P.3d 1012, 1018 n.12 (Or. Ct. App. 2005) 
Aggregate Litigation, which was recently approved by the American Law Institute. ${ }^{8}$ In sharp contrast to the longstanding position of the Institute, ${ }^{9} \quad$ Aggregate Litigation seeks to narrow substantially the traditional availability of collateral attack for inadequate representation.

(citing Epstein for the proposition that "collateral second-guessing of the adequacy of notice and representation in a prior class action is inappropriate"); Wilkes ex rel. Mason v. Phoenix Home Life Mut. Ins. Co., 902 A.2d 366, 382 (Pa. 2006) (citing Stephenson for the proposition that "[w]hen a class member collaterally attacks a class settlement by alleging that he was wrongfully included in the class ... we believe the allegation should be permitted substantive collateral review because a class settlement does not always protect the interests of every party subject to it"); Lamarque v. Fairbanks Capital Corp., 927 A.2d 753, 760-65 (R.I. 2007) (adopting the view that "the extent of collateral review is limited to consideration of "whether the procedures in the prior litigation afforded the party against whom the earlier judgment is asserted a full and fair opportunity to litigate the claim or issue'"); Hospitality Mgmt. Assoc., Inc. v. Shell Oil Co., 591 S.E.2d 611, 616-20 (S.C. 2004) (same holding as Lamarque); Kortebein v. Am. Mut. Life Ins. Co., 49 S.W.3d 79, 88 (Tex. App. 2001) (stating that "[d]ue process does not require collateral second-guessing" of class determinations) (citing Epstein v. MCA, Inc., 179 F.3d 641, 648 (9th Cir. 1999)); Vermont v. Homeside Lending, Inc., 826 A.2d 997, 1017 (Vt. 2003) ("If we had to decide this case squarely on this issue, we would be inclined to follow the recent decision of the Second Circuit Court of Appeals in Stephenson because adequacy of representation is 'the quintessence of due process in class actions."'); Nobl Park, LLC v. Shell Oil Co., 95 P.3d 1265, 1269 \& n.3, 1270-71 (Wash. Ct. App. 2004) (entertaining a collateral attack on adequate representation after construing Epstein to mean that a court is not required to but may entertain a collateral attack on a class judgment). Two decisions that slightly pre-date the decade and will not otherwise be mentioned should also be noted. See Twigg v. Sears, Roebuck \& Co., 153 F.3d 1222, 1226 (11th Cir. 1998) ("[A]n absent class member may collaterally attack the prior judgment on the ground that to apply claim preclusion would deny him due process." (citations omitted)); Williams v. Gen. Elec. Capital Auto Lease, Inc., 159 F.3d 266, 269-70 (7th Cir. 1998) (stating that an absent "class member could try to show in a collateral attack that the decision to proceed before a magistrate judge was a matter on which there was a potential (or, in the light of the fully developed record, an actual) significant intra-class conflict and that the notice the absentee received was inadequate to inform her of this conflict").

8. A.L.I., Principles of the LaW of Aggregate Litigation (Proposed Final Draft 2009) [hereinafter AGgREGATE LiTigation]. The proposed final draft was approved for publication as the official text of the Principles "subject to the discussion at... the 2008 [and 2009] Annual Meeting[s] and also to editorial prerogative." See www.ali.org/index.cfm? fuseaction= meetings.annual_updates_09 (last visited Dec. 9, 2009). In textual references, I refer to the proposed final draft as Aggregate Litigation.

9. The First Restatement of Judgments is crystal clear: "Where a person is not a party to a class action, the judgment therein has conclusive effect against him only if his interests were adequately represented.... A person as to whom a class action is ineffective is not required to seek relief during the continuance of the action.” RESTATEMENT OF JUDGMENTS $§ 116 \mathrm{cmt}$. b (1942). The Second Restatement is in accord:

$[\mathrm{N}]$ otice concerning designation of a representative is an invitation to dispute the propriety of the designation and does not foreclose the notified party from later contesting the adequacy of the representation and on that basis avoiding the conclusive effect of a judgment involving the representative. The purpose of offering opportunity to dispute the fitness of the representative is to permit anticipation of the possibility of subsequent attack on his authority and thus to assure as far as possible that the judgment in the action will have conclusive effects.

RESTATEMENT (SECOND) OF JUDGMENTS $§ 42 \mathrm{cmt}$. b (1982) (contrasting the use of notice in class actions with process in ordinary litigation); $c f$. id. at cmt. e reporter's note (citing Hansberry for the proposition that "[t]he finding of divergence of interest may, of course, be made on collateral challenge" (emphasis added)). 
Specifically, Aggregate Litigation argues that collateral attack should be prohibited unless the class court "failed to make the necessary findings of adequate representation, or failed to afford class members reasonable notice and an opportunity to be heard as required by applicable law."10 Aggregate Litigation provides little assistance in defining what constitutes "the necessary findings of adequate representation," goal clearly is to move away from the traditional rule that absent class members are not bound by the finding of the class court that they have been adequately represented.

Aggregate Litigation also seeks to rewrite the constitutional meaning of "adequacy of representation," defining it exclusively in terms of "structural conflicts." 12 In support of that position, the Reporters point to an article written by two of them-Samuel Issacharoff and Richard Nagareda. ${ }^{13}$ Professors Issacharoff and Nagareda draw a sharp distinction in that article between "structural defects" and "performance defects" in the representation of a class and argue that even a limited form of collateral attack should be available only when inadequate representation is caused by a structural defect. ${ }^{14}$

I published an article a decade ago arguing that the efforts to limit collateral attacks were inconsistent with the proper interpretation of class action rules and the Constitution. ${ }^{15}$ In this Article, I revisit the issue of

10. Aggregate Litigation, supra note $8, \S 3.14(\mathrm{a})(2)$. Aggregate Litigation also recognizes that a collateral attack is permissible if the court rendering the class judgment lacks subject-matter or personal jurisdiction. Id. As I have long argued, states lack power under the Constitution to exercise personal jurisdiction over absent class members who have been inadequately represented, unless those class members have minimum contacts with the forum; it seems clear that Aggregate Litigation does not agree. Id., $\S 3.14 \mathrm{cmt}$. a (noting that postjudgment challenges may be permissible if the court lacked personal jurisdiction but insisting that "[t]his Section does not approve of postjudgment challenge as a vehicle for relitigating findings of adequacy of representation that were made prior to judgment by the court approving the settlement").

11. Id. $\S 3.14(\mathrm{a})(2)$.

12. Id. $\S 2.07 \mathrm{cmt}$. d. Structural conflicts are defined narrowly by Aggregate Litigation as those that "present a significant risk that the conduct of the litigation will be skewed systematically-that is, in some direction predictable before the determination of related claims on an aggregate basis." Id.

13. Id. $\S 2.07 \mathrm{cmt}$. d reporters' notes. In their article, Professors Issacharoff and Nagareda carefully note: "The views stated herein represent our shared assessment as commentators, not necessarily the position of the ALI." Issacharoff \& Nagareda, supra note 6, at $1649 \mathrm{n} .{ }^{\dagger \dagger}$. The other Reporters were Robert Klonoff and Charles Silver. Id.

14. Id. at 1677-1700. Professors Issacharoff and Nagareda further contend that collateral attacks should be available for structural defects only if the court rendering the class judgment failed to address adequately an argument that the structure of the class was defective. Id. at 1714-18. They would also require that collateral attacks in some circumstances be filed in the rendering court. See id. at 1713 ("Where the class action is in a particular federal forum as a result of congressional determination that (1) the case is one of national-market significance, and (2) a single forum needs to be created, then collateral attacks should be directed to the rendering federal court.").

15. Woolley, supra note 3. I recognized that class action rules could be rewritten to limit 
collateral attack for inadequate representation in light of the recently approved Principles of the Law of Aggregate Litigation and the supporting scholarship of Professors Issacharoff and Nagareda. ${ }^{16}$ In Part II, I critique Aggregate Litigation's extraordinarily narrow conception of adequate representation and argue for an understanding that takes into account the performance of class counsel. ${ }^{17}$ In Part III, I challenge a central assumption of Aggregate Litigation's effort to severely limit the availability of collateral attack-the assumption that adequate representation plays no role in a proper analysis of personal jurisdiction. I show why recognition of the jurisdictional nature of adequate representation is mandated by a sound understanding of the principles governing personal jurisdiction in United States courts. Part III also explains why efforts to limit collateral attack by relying on virtual representation or the fiduciary role of the class court stretch the principles of preclusion law beyond the breaking point. I conclude in Part IV.

\section{The MEANING OF AdEQUATE REPRESENTATION}

\section{A. A Bird's-Eye View of the Debate}

\section{The Traditional Approach to Adequate Representation}

The foundation of the traditional approach to adequate representation rests on the recognition that the "interest" protected by the adequate representation requirement is the constitutionally-protected property interest of an individual class member in his or her claim. ${ }^{18}$ As I have

collateral attack in some circumstances, but argued that sound public policy counseled against limits on collateral attack outside the context of structural injunctions. Id. at 432-45.

16. See supra note 6. My primary focus in this Article is on Class Settlements Under Attack, the article jointly published by Professors Issacharoff and Nagareda while at work on Aggregate Litigation. I have previously critiqued the views expressed in Professor Nagareda's earlier work. See Patrick Woolley, Shutts and the Adequate Representation Requirement, 74 UMKC L. REV. 765 (2006) [hereinafter Woolley, Shutts and the Adequate Representation Requirement]; Patrick Woolley, Choice of Law and the Protection of Class Members in Class Suits Certified Under Federal Rule of Civil Procedure 23(b)(3), 2004 MiCH. ST. L. REV. 799 (2004) [hereinafter Woolley, Choice of Law].

17. My first article on collateral attack gave only glancing attention to the content of the adequate representation requirement, Woolley, supra note 3, at 433-34, but it has since become clear that it is impossible to adequately address the availability of collateral attack separately from the content of the adequate representation requirement. I have considered the content of the adequate representation requirement in two other articles. See Woolley, Shutts and the Adequate Representation Requirement, supra note 16, at 771-77; Woolley, Choice of Law, supra note 16, at 818-36. I draw here on my discussion of adequate representation in those earlier articles.

18. See Patrick Woolley, Rethinking the Adequacy of Adequate Representation, 75 TEX. L. 
noted, "[a] claim - whether resolved by judgment after adjudication or sold to a defendant in settlement-has economic value premised on entitlements granted by law."19 That individual class members have constitutionally-protected property interests in their claims does not mean, of course, that courts simply enforce preexisting substantive rights. The adjudication of claims may require "legislative" judgments by courts with respect to unsettled matters of substantive law. And in making these judgments, courts must consider what will most effectively achieve the underlying objectives of a particular statute or common-law rule. Nor are courts disabled from changing their views about the appropriate scope of a substantive right. But an individual with a constitutionally protected property interest has an entitlement to the relief prescribed by the substantive law.

A class member's property interest in his claim typically is protected by a representative or representatives authorized by a court to act on his or her behalf. ${ }^{20}$ Because it is impossible as a practical matter to ensure

REV. 571, 585 (1997) ("As the Supreme Court has made clear, a cause of action is a form of property protected by the Due Process Clause.") (citations omitted).

19. Woolley, Shutts and the Adequate Representation Requirement, supra note 16, at 771 . My discussion in this Article is limited to class suits seeking monetary relief. For a brief discussion of the "interest" at stake in class suits seeking injunctive relief, see Woolley, supra note 18, at 586-89.

20. With respect to due process, I draw no distinction between the role of the "class representative," (that is, a named plaintiff) and that of class counsel. In other words, I agree with those who have argued that from a due process perspective, adequacy of representation should be "measured first and foremost by the adequacy of counsel." Samuel Issacharoff, Governance and Legitimacy in the Law of Class Actions 1999 SUP. CT. REV. 337, 354 (1999) (internal quotation marks omitted). I recognize that this stance is controversial. See Linda S. Mullenix, Taking Adequacy Seriously: The Inadequate Assessment of Adequacy in Litigation and Settlement Classes, 57 VAND. L. REV. 1687, 1695, 1703-11 (2004) (treating "judicial finding of both adequacy of the class representatives as well as of the proposed class counsel" as a due process requirement and criticizing the lack of attention paid to the adequacy of class representatives); see also In re General Motors Corp. Pick-Up Truck Fuel Tank Prods. Liab. Litig., 55 F.3d 768, 784 (3d Cir. 1995) ("The protection of the absentees' due process rights depends in part on the extent the named plaintiffs are adequately interested to monitor the attorneys (who are, of course, presumed motivated to achieve maximum results by the prospect of substantial fees) ...."). I accept that in class suits asserting high-value claims, a class representative can serve a useful role in monitoring the work of class counsel. Cf. Jonathan R. Macey \& Geoffrey P. Miller, The Plaintiffs' Attorney's Role in Class Action and Derivative Litigation: Economic Analysis and Recommendations for Reform, 58 U. CHI. L. REV. 1, 19-20 (1991) (arguing that in negative-value suits "no rational plaintiff would take on the role of litigation monitor because she would incur all the costs of doing so but would realize only her pro rata share of the benefits"). But I do not believe that a monitoring role for named plaintiffs is sufficiently fundamental to be deemed a requirement of due process. The Supreme Court seems to share this view. In Taylor v. Sturgell, the Court held that preclusion based on adequate representation requires that "either the party understood herself to be acting in a representative capacity or the original court took care to protect the nonparty's interests." $128 \mathrm{~S}$. Ct. 2161, 2165 (2008) (emphasis added). In other words, the Court concluded that the plaintiff need not be aware of her representative capacity if the court otherwise protects the interests of a nonparty. See also Ortiz v. Fibreboard Corp., 527 U.S. 815, 856 (1999) (insisting on separate representation of class members with conflicts of interest to "eliminate conflicting interests of counsel" (emphasis added)). Lower 
that the representative's interests will be perfectly aligned with that of an absent class member (let alone that the representation will flawlessly advance the interests of the absent class member), the law requires only adequate representation. But to the extent practicable, adequate representation must be defined in a manner designed to protect the property interests of individual class members in their claims. ${ }^{21}$ Generally speaking, settlements in class suits for money damages should respect the relative economic value of individual claims or categories of individual claims. To give class counsel broad discretion to disregard the relative value of class claims would essentially permit class counsel to rewrite the substantive law; that class counsel has no authority to do. The Court recognized this fundamental principle in Amchem and Ortiz, rejecting those settlements in substantial part on the ground that they did not adequately protect the value of claims held by certain class members. ${ }^{22}$

Because the "interest" to be protected in a class suit is the interest of each individual in the economic value of his or her claim, the conflicts of interest to be avoided are those that would create an unacceptable risk that an absent class member will not recover the economic value of his or her claim. But courts also have an obligation to ensure that unavoidable conflicts of interest do not prejudice absent class members. Class counsel similarly has a duty to exercise reasonable care and due diligence in protecting the economic value of all the individual claims within the representation. ${ }^{23}$

courts seem to be moving in the same direction. See Robert H. Klonoff, The Judiciary's Flawed Application of Rule 23's “Adequacy of Representation” Requirement, 2004 MicH. ST. L. REV. 671, 678 (2004) (noting critically "the holding by 228 courts (about 30 percent of the cases ruling on adequacy) during the 10-year period studied that class representatives were per se adequate because their claims did not conflict with those of the class"). I do not consider whether Rule 23-as opposed to the Due Process Clause - requires that named plaintiffs actively act as fiduciaries of the class. Cf. James D. Cox et al., Does the Plaintiff Matter? An Empirical Analysis of Lead Plaintiffs in Securities Class Actions, 106 Colum. L. Rev. 1587, 1600 (2006) (stating that the Private Securities Litigation Act "empowers the lead plaintiff to 'select and retain' counsel with the approval of the court, which envisions the possibility that the lead plaintiff may substitute counsel so as to bring an early conclusion to the case" (footnote omitted)).

21. It is for this reason that I reject the "hypothetical consent standard" formulated by Geoffrey Miller. See Geoffrey P. Miller, Conflicts of Interest in Class Action Litigation: An Inquiry into the Appropriate Standard, 2003 U. CHI. LEGAL F. 581, 596 (2003) ("[B]ecause the reasonable plaintiff is shielded from knowledge of her position, the hypothetical consent standard requires that the decision be in the best interest of the class as a whole ....").

22. Ortiz, 527 U.S. at 864-65; Amchem Prods., Inc. v. Windsor, 521 U.S. 591, 620-29 (1997).

23. In a counterfactual world in which all interested parties knew that a class suit would be litigated to judgment, assessing the adequacy of representation would be relatively easy. In such a world, conflicts of interest within the class would be less likely, though certainly not out of the question; counsel often should be able to vigorously pursue judgment for every member of the class without negatively affecting any other member of the class. Nor would conflicts between counsel 


\section{The Aggregate Litigation Approach}

One of the most striking features of Aggregate Litigation is its effort to rewrite the law's understanding of adequate representation - the key due-process concept in class litigation. In an article cited by Aggregate Litigation on this point, Professors Issacharoff and Nagareda distinguish between "structural defects" in representation, which may justify collateral attacks, and "performance defects," which do not. ${ }^{24}$ Structural defects are conflicts that "present a significant risk that the conduct of the litigation will be skewed systematically - that is in some direction predictable prior to the determination of related claims on an aggregate basis." ${ }^{25}$ That kind of defect, Professors Issacharoff and Nagareda argue, is of constitutional dimension because it "bespeaks a proceeding illegitimate from its conception." ${ }^{26}$ By contrast, they sharply reject the view that a "claim of subpar performance [by counsel may] assume the mantle of a constitutional affront." 27 In short, Professors Issacharoff and Nagareda would create a hierarchy of representational defects, permitting even limited collateral review only with respect to "structural defects." Aggregate Litigation takes the same approach. ${ }^{28}$

and the class as a whole be likely if counsel were to share in the recovery obtained for the class. The central inquiry in such a world would often revolve around whether counsel litigated the action with sufficient care and skill.

But settlement is almost always the way plaintiffs in class litigation obtain a remedy in the real world. The funds a defendant is willing to set aside for settlement will usually be limited, so there will normally be competition among different segments of the class for limited settlement funds. See Miller, supra note 21, at 602 n.71 ("An inevitable aspect of any settlement is the task of allocating the limited proceeds among class members."). Moreover, it may be possible in class suits resolved through settlement for class counsel to obtain (additional) attorneys' fees by selling out the class or a segment of the class. In short, the dynamics of settlement significantly increase the risk that absent class members will be inadequately represented.

24. Issacharoff \& Nagareda, supra note 6 , at 1659.

25. AgGRegate Litigation, supra note $8, \S 2.07 \mathrm{cmt}$. d ("The objective . . is for the court to determine whether conflicts of interest are such as "would present a significant risk that the lawyers for claimants might skew systematically the conduct of the litigation so as to favor some claimants over others on grounds aside from reasoned evaluation of their respective claims or to disfavor claimants generally vis-à-vis the lawyers themselves." (quoting id. at $\S 2.07(\mathrm{a})(1)(\mathrm{B}))$ ). Although Professors Issacharoff and Nagareda use the terms "structural defect" and "performance defect," Aggregate Litigation does not. See, e.g., id. $\S 2.07 \mathrm{cmt}$. d ("Subsection (a)(1) casts the right of loyalty as the absence of structural conflicts of interest in the representation of claimants on an aggregate basis.").

26. Issacharoff \& Nagareda, supra note 6, at 1700.

27. Id. at 1658 .

28. Section 2.07(a) "organizes the due-process rights of claimants in aggregate proceedings on related claims," but omits any consideration of whether counsel acted with adequate skill. AgGREGAte Litigation, supra note $8, \S 2.07 \mathrm{cmt}$. c. Aggregate Litigation also rules out the use of collateral attack to relitigate a finding of adequate representation made by the class court prior to judgment. Id. $\S 2.07 \mathrm{cmt}$. d (stating that Section 2.07 "consciously implies that a judicial finding of 
The goal seems to be to promote finality by making it possible to determine in advance of settlement-and without considering the terms of the settlement-whether the adequate-representation requirement has been satisfied. But this approach thoroughly misconceives the basis of the adequate-representation requirement. The key constitutional question is not whether a decision to aggregate was legitimate $a b$ initio, ${ }^{29}$ but whether it is fundamentally fair to bind a particular person to the class judgment. ${ }^{30}$

Certification of a class by a court constitutes a promise that the interests of class members in the litigation will be adequately protected. As the Supreme Court explained in Phillips Petroleum Co. v. Shutts, "a class action plaintiff is not required to fend for himself.... The court and named plaintiffs protect his interests." 31 Because absent class members, relying on the promise that their interests will be protected, may choose not to participate in the class suit, fundamental fairness requires that that promise be kept if class members are to be bound. ${ }^{32}$ But given the extraordinary emphasis that Aggregate Litigation-and Professors Issacharoff and Nagareda-place on finality, ${ }^{33}$ it is not

loyalty as part of the decision to aggregate-like a determination made on the merits in the aggregate proceeding - should have preclusive effect, unless challenged on direct appeal"); id. $\S 3.14 \mathrm{cmt}$. a. ("This Section does not approve of post-judgment challenge as a vehicle for relitigating findings of adequacy of representation that were made prior to judgment by the court approving the settlement.").

29. Issacharoff \& Nagareda, supra note 6, at 1657-58.

30. Professors Issacharoff and Nagareda conflate the authority to aggregate with the authority to bind. But they are not the same. Cf. Hansberry v. Lee, 311 U.S. 32, 42 (1940) ("It is evident that the considerations which may induce a court thus to proceed, despite a technical defect of parties, may differ from those which must be taken into account in determining whether the absent parties are bound by the decree or, if it is adjudged that they are, in ascertaining whether such an adjudication satisfies the requirements of due process and of full faith and credit.").

31. 472 U.S. 797, 809 (1985).

32. Cf. Woolley, supra note 3, at 393 n.30 and accompanying text. To the extent that absent class members can be bound without notice or an opportunity to be heard, adequate representation serves as a substitute for the opportunity to be heard - what the Court has called the "fundamental requisite of due process." Mullane v. Cent. Hanover Bank \& Trust Co., 339 U.S. 306, 314 (1950) (citing Grannis v. Ordean, 234 U.S. 385, 394 (1914)). I have argued elsewhere that individual class members who choose not to rely on the class representative are entitled to notice and an opportunity to be heard. See Woolley, supra note 18, at 599-619.

33. AgGRegate Litigation, supra note $8, \S 2.02 \mathrm{cmt}$. e. ("[I]f a determination in the aggregate would occur only amidst doubts about its preclusive effect, then those concerns should stand as warning signs counseling strongly against aggregation in the first place."); Issacharoff \& Nagareda, supra note 6, at 1651 ("Our aim in this Article is to provide a cohesive framework for establishing the finality of class actions under the real-world conditions of settlement."). Professors Nagareda and Issacharoff argue that the "repose" offered by a settlement is a crucial part of a defendant's calculations in settling a claim. Id. But see Dana, supra note 3, at 321-30 (arguing that the "chilling effect" of collateral challenges is often overstated). In any event, the recognition that the availability of collateral attack may negatively affect the economic value of claims in general is only one factor in determining whether the legal system should make collateral attack available. 
surprising that they choose to advance a narrow conception of adequacy, notwithstanding its inability to protect absent class members from misconduct by class counsel that cannot be predicted at the outset of the litigation.

Focusing on whether the decision to aggregate was legitimate $a b$ initio also has the effect of giving the court and class counsel wide discretion to modify the preexisting rights of class members. ${ }^{34}$ Professor Nagareda, for example, has argued that class suits "stand uneasily between the categories of rulemaking and adjudication." "35 He describes class settlements designed by class counsel and their defense counterparts as tending "to amount to a kind of privatized civil justice reform, positing the displacement of class members' preexisting rights as delineated by legislatures or common-law courts." 36 "Class action law," he contends, "should acknowledge forthrightly the power of governance wielded via class settlements - it should see class actions as an institutional rival to conventional processes of law reform . . .."37

Treating the class device as a form of governance validates the use of the class device to subordinate a class member's interest in his or her individual claim to other social objectives - for example, ensuring that defendants are adequately deterred from engaging in future conduct the law has deemed harmful. From this perspective, the details of compensation are less important than the effectiveness of the deterrent, and inadequate representation of class members is of serious concern only if it interferes with deterrence. ${ }^{38}$ But the decision to create individual causes of action gives rise to legitimate expectations that are entitled to constitutional protection as a form of property. ${ }^{39}$ The adequate representation requirement must be designed to adequately protect these entitlements. ${ }^{40}$

34. Issacharoff \& Nagareda, supra note 6, at 1658.

35. Nagareda, Administering Adequacy, supra note 6, at 355.

36. Richard A. Nagareda, The Preexistence Principle and the Structure of the Class Action, 103 COLUM. L. REV. 149, 152 (2003).

37. Nagareda, Administering Adequacy, supra note 6, at 292.

38. A related objective in large-scale class suits has often been to modify the rights of class members in a way that will make it easier to deal "fairly and efficiently" with a particular mass injury - a phenomenon Richard Marcus noted in the mass-tort context years ago. Richard L. Marcus, They Can't Do That, Can They? Tort Reform Via Rule 23, 80 CORnell L. REV. 858, 870 (1995) ("[The agreements] implement an alternative to the tort system that is responsive to the federal courts' substantive concerns about mass torts.").

39. See Woolley, supra note 18, at 585 n.64.

40. It should be noted that, as a practical matter, the two models I have laid out in the text converge in the context of negative-value claims. By negative-value claims, I mean claims too small to make individual litigation worthwhile. Because individual litigation of negative-value claims is impracticable, the aggregation of individual causes of action in a class suit provides absent class 


\section{B. The Performance of Counsel}

Aggregate Litigation - and Professors Issacharoff and Nagaredaargue that inadequate performance of class counsel's obligations cannot give rise to a constitutional defect. ${ }^{41}$ But as the Supreme Court noted as early as Hansberry v. Lee, the Due Process Clause is satisfied only if class "litigation is so conducted as to insure the full and fair consideration of the common issue." 42 This passage cannot be understood to simply require that good procedures be put in place or that class suits be free of structural conflicts. Hansberry requires that class action procedure be "so devised and applied as to insure that those present are of the same class as those absent and that the litigation [be] so conducted as to insure the full and fair consideration of the common issue." 43 Shutts is in accord. If the only defects that mattered to an assessment of adequate representation were structural defects - that is, defects that "present a significant risk that the conduct of the litigation will be skewed systematically... in some direction predictable before the determination of related claims on an aggregate basis" would have been no need for the Shutts Court to stress that there must be adequate representation "at all times." 45

Following the Court's lead in Hansberry, the Fifth Circuit held in Gonzales v. Cassidy that

the primary criterion for determining whether the class representative has adequately represented his class for purposes of res judicata is whether the representative, through qualified counsel, vigorously and tenaciously protected the interests of the class. A court must view the

members with an opportunity to receive compensation for injuries that would not be compensable otherwise. It is certainly reasonable in that context to place greater emphasis on the deterrent aspects of the law in administering class suits in which individual litigation would be impracticable. But with respect to positive-value class claims, the choice of model matters a great deal because the entitlement to the relief prescribed by law has significant value.

41. Issacharoff \& Nagareda, supra note 6, at 1657-58 (complaining that using the term "adequate representation" to include performance defects "allows even a claim of subpar performance to assume the mantle of a constitutional affront"). Professors Issacharoff and Nagareda dismissively argue that "agency problems abound in all legal representation." Id. at 1699. But there are only a handful of contexts in which the state guarantees adequate representation.

42. 311 U.S. 32, 43 (1940) (emphasis added).

43. Id. (emphasis added). See also id. at 42-43 ("It is familiar doctrine of the federal courts that members of a class not present as parties to the litigation may be bound by the judgment where they are in fact adequately represented by parties who are present, or where they actually participate in the conduct of the litigation in which members of the class are present as parties ....") (emphasis added).

44. AgGregate Litigation, supra note $8, \S 2.07 \mathrm{cmt}$. d.

45. Phillips Petroleum Co. v. Shutts, 472 U.S. 797, 812 (1985). 
representative's conduct of the entire litigation with this criterion as its guidepost. $^{46}$

"'Vigorous' and 'tenacious' protection requires, at a minimum, that counsel pursue their clients' claims, make a reasonable effort to assess the fair settlement value of those claims, and pursue a settlement that approximates that value, always taking into account the ever-present risks of litigation." 47 The Second Restatement, for its part, requires that a representative act with "due diligence and reasonable prudence."48

46. 474 F.2d 67, 75 (5th Cir. 1973); see also id. at 74 ("Due process of law would be violated for the judgment in a class suit to be res judicata to the absent members of a class unless the court applying res judicata can conclude that the class was adequately represented in the first suit." (citing Hansberry, 311 U.S. at 61)); Pelt v. Utah, 539 F.3d 1271, 1284-86 (10th Cir. 2008) (noting that "[d]ue process requires adequate representation 'at all times' throughout the litigation" and that "“[ $t$ ]he question of adequate representation can best be resolved by determining whether the interests of those who would attack the judgment were vigorously pursued and protected in the class action by qualified counsel'”); Epstein v. MCA, Inc., 126 F.3d 1235 (9th Cir. 1997) (“Adequate representation requires that counsel "vigorously and tenaciously protect[ ] the interests of the class." (quoting Gonzales, 474 F.2d at 75)), vacated on other grounds, 179 F.3d 641 (9th Cir. 1999); Key v. Gillette Co., 782 F.2d 5, 7 (1st Cir. 1986) (affirming decertification of a class for lack of adequate representation when the "district court found that the weak presentation of the individual discrimination claim, the serious deficiencies in the methodology of the principal expert, the failure of appellant's attorney to present the expert's testimony in a manner that could be understood by the court and his general lackluster performance during trial all reflected appellant's inability to 'fairly and adequately protect the interests of her class"'); Keene v. United States, 81 F.R.D. 653, 657 (S.D. W. Va. 1979) (quoting Gonzales for the proposition that the general test of the adequacy of the representation in a class action is whether the class representative, through qualified counsel, "“vigorously and tenaciously protected the interests of the class"'); Lewis v. Philip Morris, Inc., 419 F. Supp. 345, 352 (E.D. Va. 1976) (recognizing that "[t]he generally accepted standard to be employed for determining whether the class was adequately represented... is whether the class representatives, through their counsel, vigorously and tenaciously protected the interests of the entire class"), vacated sub nom. on other grounds, Lewis v. Tobacco Workers' Int'l Union, 577 F.2d 1135 (4th Cir. 1978); Johnson v. Shreveport Garment Co., 422 F. Supp. 526, 534 (W.D. La. 1976) ("The implication of the cases concerning adequacy of representation is that a party who wishes to prosecute an action on behalf of a class must protect the rights and interests of absent class members vigorously, tenaciously and effectively."), aff'd, 577 F.2d 1132 (5th Cir. 1978); Clark v. S. Cent. Bell Tel. Co., 419 F. Supp. 697, 702 (W.D. La. 1976) (noting that "if the class case has not been presented fully, it would be unfair and unconstitutional to bind absent parties"); Dolgow v. Anderson, 43 F.R.D. 472, 496 (E.D.N.Y. 1968) (citing Hansberry for the proposition that the representation of a class "might be so poor that the judgment would not have any res judicata effect"), rev'd on other grounds, 438 F.2d 825 (2d Cir. 1970).

47. Epstein, 126 F.3d at 1251.

48. Restatement (SECOND) OF Judgments $\S 42$ (1982). The Restatement provides in relevant part:

(1) A person is not bound by a judgment for or against a party who purports to represent him if:

$$
\text { .... }
$$

(e) The representative failed to prosecute or defend the action with due diligence and reasonable prudence, and the opposing party was on notice of facts making that failure apparent.

Id. (emphasis added). See also id. cmt. f reporter's note ("In class actions at least, the failure to 
It should be obvious that adequate lawyering is essential to the full and fair consideration of class claims required by Hansberry. ${ }^{49}$ Indeed, the only plausible basis for the argument that performance defects cannot give rise to a constitutional problem is the assumption that adequate representation is simply about the legitimacy of a class proceeding $a b$ initio. But as I have argued above, adequate representation more accurately is about protecting the economic value of class claims.

This understanding is consistent with the Court's most recent decision on adequate representation, Taylor v. Sturgell. ${ }^{50}$ In Taylor, the Court faced the question of whether an individual suit by one plaintiff should be barred by an earlier suit involving the same facts brought by a later plaintiff who shared the interests of the first plaintiff. ${ }^{51}$ The plaintiffs knew each other and shared the same attorney. ${ }^{52}$ Yet the Court refused to bind the later plaintiff to the earlier judgment. ${ }^{53}$ The Court wrote:

A party's representation of a nonparty is "adequate" for preclusion purposes only if, at a minimum: (1) the interests of the nonparty and

advance a claim that has strong legal cogency may itself be regarded as a sufficient basis for refusing preclusion as to that issue."); $i d$. cmt. f illus. 11. ("A, a city taxpayer proceeding on behalf of himself and all others similarly situated, sues to restrain the city's issuance of bonds. The sole ground of A's action is that applicable procedures for issuance of the bonds have not been complied with. A dismissal of the action does not preclude a subsequent taxpayer's action by B contending that the purpose for which the bonds are issued is unlawful, if that contention has such substantial merit that competent counsel would reasonably have asserted it in the first action.")

"The Restatement treats membership in the class as a prerequisite to serving as a class representative." Woolley, supra note 3, at 425 (citing RESTATEMENT (SECOND) OF JUDGMENTS § 41 (1982)). But "[b]ecause the representative in a class suit necessarily prosecutes the action through counsel, it seems reasonable to treat section 42(1)(e) as reaching class counsel's failure to prosecute the action with due diligence." Id.; see also supra note 20 (arguing that class representatives are essentially figureheads). For an argument that the last clause of $\S 42(1)(\mathrm{e})$ makes subsection e weaker than required by the Constitution, see Woolley, supra note 3, at 422-28.

49. In fact, Professor Rubenstein has argued that the requirements of adequate representation in class litigation are best compared to the requirements of ineffective assistance of counsel in the Sixth Amendment context. Rubenstein, supra note 1, at 857; see also Tobias Barrington Wolff, Preclusion in Class Action Litigation, 105 COLUM. L. REV. 717, 805-06 (2005) (recognizing that in some circumstances the adequacy analysis must focus on the representation provided by counsel and suggesting that the Sixth Amendment line of cases may be helpful); Geoffrey C. Hazard, Jr. et al., An Historical Analysis of the Binding Effect of Class Suits, 146 U. PA. L. REV. 1849, 1855 (1998) ("If the interests of the class are presented with reasonable competence and vigor, then courts will be on safe ground in treating members of the class as bound even if they did not actually participate in the litigation. This concept is also formulated in various ways, notably as whether the representatives 'fairly and adequately protect the interests of the class' or 'prosecute or defend the action with due diligence and reasonable prudence."” (footnotes omitted)).

50. 128 S. Ct. 2161 (2008).

51. Id. at 2167 .

52. Id. at 2169.

53. Id. at 2178 . 
her representative are aligned, and (2) either the party understood herself to be acting in a representative capacity or the original court took care to protect the interests of the nonparty. In addition, adequate representation sometimes requires (3) notice of the original suit to the persons alleged to have been represented.

One might read the passage quoted above as comprehensively stating the requirements of adequate representation. But it seems unlikely that the Court intended to suggest that the adequate representation requirement can be satisfied by incompetent counsel, for example. ${ }^{55}$ The question presented in Taylor was not whether counsel adequately represented the later plaintiff in the second suit, but whether the later plaintiff was represented at all in the first suit. ${ }^{56}$ As Hansberry noted, adequate representation is about ensuring the full and fair consideration of the common issue. ${ }^{57}$ That goal cannot be achieved if a party is represented by deficient counsel.

But even if Taylor could be read to suggest that performance defects alone cannot give rise to inadequate representation, the case provides no support for the contention that only one kind of structural conflict may lead to inadequate representation. Taylor speaks broadly of a requirement that "the interests of the nonparty and her representative [be] aligned"58 without providing any further detail. Because most performance defects in the class context are inextricably intertwined with structural conflicts, Taylor is of limited significance even if read broadly to suggest that performance defects alone cannot give rise to inadequate representation.

54. Id. at 2176 (citations omitted). The Court in Taylor treats notice in this context as a requirement of adequate representation rather than as an independent requirement. In so doing, the Court arguably misreads Richards and misconceives the relationship between adequate representation and notice. For a different take on Richards and on the proper relationship between notice and adequate representation, see Woolley, supra note 18, at 573-74, 582-83.

55. See Pelt v. Utah, 539 F.3d 1271, 1286-87 (10th Cir. 2008) (holding that satisfaction of the minimum requirements in Taylor does not resolve whether the representation afforded to absent class members satisfies the Due Process Clause).

56. No claim was made in Taylor that the lawyering in the first suit had been deficient. The only issue before the Court was whether Taylor could be bound by a judgment in an earlier suit which neither the purported representative nor the court had understood to be representative. Taylor, $128 \mathrm{~S}$. Ct. at 2167-70. That is not to say that the performance of the plaintiff's lawyer in the first suit was flawless. At least in retrospect, he appears to have erred in failing to challenge on appeal certain assumptions underlying the District Court's alternative holding in favor of the defendants. The Court of Appeals affirmed the alternative holding, but refused to rule on whether the critical suppositions on which the alternative holding was premised were true. Id. at 2168.

57. Hansberry v. Lee, 311 U.S. 32, 43 (1940).

58. Taylor, $128 \mathrm{~S}$. Ct. at 2165. 


\section{Structural Conflicts}

\section{Aggregate Litigation's Standard}

Aggregate Litigation - and Professors Issacharoff and Nagareda-err in assuming that the only relevant conflicts of interest from a constitutional perspective are those that create structural defects ${ }^{59}$ - that is, conflicts that give rise to inadequate representation per se. ${ }^{60}$ Some structural conflicts - such as those between counsel and the class-are inevitable and cannot be considered structural defects per se. ${ }^{61}$ Yet, Aggregate Litigation - and Professors Issacharoff and Nagareda-would simply disregard such conflicts, unless at the outset of the litigation they " "present a significant risk that lawyers for the claimants might skew systematically the conduct of the litigation." 62 A "significant risk," by definition, does not include the background risk inherent in any agency relationship. $^{63}$ This narrow standard provides some protection against conflicts between class counsel and the class. But, as I will demonstrate below, it fails to adequately protect an absent class member's interest in the economic value of his or her claim. For that reason, the impact of all structural conflicts on the class suit should be assessed before concluding that an absent class member has been adequately represented.

59. I have drawn a distinction between "conflicts" and "defects" in my discussion because not every class conflict represents an impermissible defect in representation.

60. Issacharoff \& Nagareda, supra note 6, at 1656-57 (distinguishing "structural conflicts of interest" from class counsel's decision to "shirk responsibility by accepting an inadequate settlement so as to gain quickly at least some modicum of a fee award from the litigation").

61. See State v. Homeside Lending, Inc., 826 A.2d 997, 1013 (Vt. 2003) ("[W]e recognize that especially with respect to attorney's fees, attorneys for the class in a damages action often have an unavoidable conflict of interest with the class that does not make their representation inadequate per se."); Howard M. Downs, Federal Class Actions: Diminished Protections for the Class and the Case for Reform, 73 NEB. L. REV. 646, 657 (1994) ("Invariably direct conflicts arise between class counsel, the class, and its representatives with respect to attorneys' fees, settlement, fee sharing, and other issues.").

62. AGGREGATE LitigATION, supra note $8, \S 2.07 \mathrm{cmt}$. d ("The objective . . is for the court to determine whether conflicts of interest are such as "would present a significant risk that the lawyers for the claimants might skew systematically the conduct of the litigation so as to favor some claimants over others on grounds aside from the reasoned evaluation of their respective claims or to disfavor claimants generally vis-à-vis the lawyers themselves."); id. ("[T]he judicial inquiry in subsection (a)(1) focuses on conflict . . . that is such as to present a significant risk that the conduct of the litigation will be skewed systematically - that is, in some direction predictable before the determination of related claims on an aggregate basis."); see also Issacharoff \& Nagareda, supra note 6 , at 1684 (arguing that with respect to intra class conflicts, the differences "that matter are those that give rise to a significant potential for negotiation on behalf of an undifferentiated class to skew in some predictable way the design of class-settlement terms in favor of one or another subgroup for reasons unrelated to evaluation of the relevant claims").

63. See Issacharoff \& Nagareda, supra note 6, at 1699-1700 (discussing the difficulties in these agency relationships). 
Aggregate Litigation's focus on one particular kind of structural conflict - those "that would present a significant risk that the lawyers for claimants might skew systematically the conduct of the litigation" ${ }^{\text {" }}$ purports to draw inspiration from Amchem and Ortiz. In rejecting the settlement in those cases, the Court stressed the structural defects in the classes that made it difficult for one set of lawyers to protect the interests of all class members. ${ }^{65}$ The structural defects that the Court highlighted did in fact "present a significant risk" from the outset that conduct of the settlement negotiations would be "skew[ed] systematically" to "favor some claimants over others." The Court accordingly concluded that the class should have been structured ab initio so as to avoid the conflicts of interest it identified:

The class representatives may well have thought that the Settlement serves the aggregate interests of the entire class. But the adversity among subgroups requires that the members of each subgroup cannot be bound to a settlement except by consents given by those who understand that their role is to represent solely the members of their respective subgroup. ${ }^{67}$

Aggregate Litigation - and Professors Issacharoff and Nagaredaalso recognize that a conflict between class counsel and the class as a whole may sometimes constitute a "structural defect." ${ }^{\text {"68 }}$ They cite as an

64. AgGREGAte Litigation, supra note $8, \S 2.07(\mathrm{a})(1)(\mathrm{B})$.

65. Ortiz v. Fibreboard Corp., 527 U.S. 815, 864-65 (1999) (stating that it is "essential" that "intraclass conflicts [be] addressed by recognizing independently represented subclasses"); Amchem Prods., Inc. v. Windsor, 521 U.S. 591, 595 (1997) (finding that "the settling parties achieved a global compromise with no structural assurance of fair and adequate representation").

66. AGGREGATE LitigATION, supra note 8, § 2.07(a)(1)(B).

67. Amchem, 521 U.S. at 627 (citing In re Joint E. \& S. Dist. Asbestos Litig., 982 F.2d 721, 742-43 (2d Cir. 1992), modified, 993 F.2d 7 (2d Cir. 1993)). As I have previously noted:

$[\mathrm{T}]$ he requirement that easily identifiable categories of claimants be separately represented serves primarily to insure that, when practicable, each easily identified category of claimants will be represented by class counsel who does not have conflicting loyalties to other segments of the class. The Court expressly recognized this fundamental point in Ortiz when it insisted on "separate representation to eliminate conflicting interests of counsel."

Woolley, Shutts and the Adequate Representation Requirement, supra note 16, at 773 (quoting Ortiz, 527 U.S. at 856).

68. See AGGREGAte LitigAtion, supra note $8, \S 2.07(\mathrm{a})(1)(\mathrm{A})$ (stating that a class court must "determine that there are no structural conflicts of interest... between the named parties or other claimants and the lawyers who would represent claimants on an aggregate basis."); see also Issacharoff \& Nagareda, supra note 6, at 1682-84. Comment d to section 2.07 explains:

Structural conflicts of interest might arise between named parties or other claimants and the lawyers who would represent claimants in the aggregate-for instance, when those lawyers also represent other persons whose claims would not be subject to aggregate treatment. As part of its inquiry, the court should consider the alignment in the economic 
example the conflict of interest in Ortiz between class counsel and the class. $^{69}$ Counsel in that case represented both the class and other plaintiffs who were expressly excluded from the class definition. As the Court in Ortiz described the problem:

$[\mathrm{S}]$ ome of the same lawyers representing plaintiffs and the class had also negotiated the separate settlement of 45,000 pending claims, the full payment of which was contingent on a successful [resolution of Ortiz]... Class counsel thus had great incentive to reach any agreement in the global settlement negotiations that they thought might survive a Rule 23(e) fairness hearing, rather than the best possible arrangement for the substantially unidentified global settlement class. ${ }^{70}$

Professors Issacharoff and Nagareda recognize that the representation by the same counsel of plaintiffs who had pending claims and class members who had not yet brought suit "presented a significant potential for class counsel to skew the design of the class-settlement terms for reasons unrelated to considered evaluation of the relevant claims ...."71 They argue that a "differently structured class ... that encompassed all pending cases [short of final judgment] would have eliminated the conflict...."72 In other words, the conflicts "amounted to disabling conflicts because of the structure of the classes involved." 73

\section{The Scope of Amchem and Ortiz}

While Amchem and Ortiz require that the class be structured $a b$ initio $^{74}$ to protect the interests of absent class members, it is a mistake to read the cases as holding that only conflicts arising from the structure of a class can give rise to constitutional problems. Indeed, Amchem and Ortiz purport to construe only the adequate representation requirement of

interests of claimants and their lawyers-for example, as reflected in the anticipated fee arrangement for representation in the aggregate proceeding. AGGREGATE LitigAtion, supra note $8, \S 2.07 \mathrm{cmt}$. d (citation omitted).

69. Id. at $\$ 2.07$, cmt. d reporters' note (explaining that Ortiz points to a conflict "between class counsel's interest in settling the class action and class counsel's interest in settling their 'inventory' cases"); Issacharoff \& Nagareda, supra note 6, at 1682-84 (citing both Amchem and Ortiz as involving unacceptable conflicts between class counsel and the class as a whole).

70. Ortiz, 527 U.S. at 852 (citations omitted).

71. Issacharoff \& Nagareda, supra note 6, at 1696. Put simply, counsel had an incentive "to compromise the interests of future claimants in exchange for advantageous aggregate settlements for [plaintiffs] with cases pending" in the court system. Id.

72. Id. at 1697.

73. Id. (emphasis added).

74. Id. at $1657-58$. 
Rule $23(\mathrm{a})(4)^{75}$ - a provision that requires a proponent of class certification to demonstrate that the named plaintiffs will adequately represent the class. In short, Rule 23(a)(4) requires a prediction that absent class members will be adequately represented. And to be reasonably predictable, a structural conflict must "present a significant risk that the conduct of the litigation will be skewed systematically- that is in some direction predictable prior to the determination of related claims on an aggregate basis." ${ }^{.76}$ But Amchem and Ortiz do not speak to the meaning of adequate representation outside the limited context of Rule 23(a)(4).

It can be argued that the prophylactic focus of Amchem and Ortiz is so indispensable as to be appropriately anchored in the Due Process Clause. ${ }^{77}$ But if proper attention is paid to the purpose of adequate representation-protecting the interests of individual class members in the economic value of their claims - there is no reason to suppose that the constitutional meaning of adequate representation can be limited to a prophylactic focus on structural conflicts. Courts cannot realistically protect the interests of absent class members by focusing solely on the absence of "structural defects" as Aggregate Litigation narrowly defines that term. ${ }^{78}$ The self-interest of lawyers, for example, may lead them to neglect the interests of the class (or segments of the class) in important ways that are not always predictable prior to settlement. This arguably is what happened in the Agent Orange litigation. ${ }^{79}$

75. Fed. R. CIV. P. 23; Ortiz, 527 U.S. at 2319-20; Amchem Prods., Inc., v. Windsor, 521 U.S. 591, 625-26 (1997). The Court in Amchem stated that Rule 23(a)(4) also "factors in competency and conflicts of class counsel." Amchem, 521 U.S. at 626 n.20.

76. AgGregate Litigation, supra note $8, \S 2.07 \mathrm{cmt}$. d.

77. Woolley, Shutts and the Adequate Representation Requirement, supra note 16, at 773 n.58 (2006) ("The prophylactic requirement that conflicting interests of "easily identifiable categories of claimants' be separately represented provides a safeguard so fundamental that it should be deemed a constitutional requirement."); Woolley, Choice of Law, supra note 16, at 819 n.66 (2004) ("Although [Amchem and Ortiz] focus exclusively on Rule 23 in their discussion of adequate representation, I agree with those who believe that the Court's interpretation of Rule 23(a)(4) simply incorporates the requirements of the Due Process Clause with respect to adequate representation."). Other commentators have also concluded that the adequate representation requirement set forth in Federal Rule 23 has constitutional stature. See, e.g., Issacharoff, supra note 20, at 352 ("The Court [in Amchem and Ortiz] redefines due process to focus centrally on the faithfulness of the agent that has litigated on behalf of the absent class members, what Rule 23 terms the adequacy of representation ....'"). But see Rubenstein, supra note 1, at 809-10 (expressing skepticism that the Court's interpretation of Rule 23(a)(4) has constitutional significance).

78. AgGRegate Litigation, supra note $8, \S 2.07 \mathrm{cmt}$. d.

79. For a comprehensive discussion of the Agent Orange litigation through 1986, see PETER SCHUCK, AgENT ORANGE ON TRIAL (1986). Others also have discussed the Agent Orange litigation in depth. See, e.g., Koniak, supra note 3, at 1817-36. Professors Issacharoff and Nagareda argue that " $[t]$ he difference that really mattered for due process purposes in Stephenson was precisely the one that the Second Circuit said did not: the same Amchem-like lumping together of both presently 


\section{The Agent Orange Litigation}

Class counsel in Agent Orange agreed to a binding settlement before development of a distribution plan ${ }^{80}$ and delegated development of a plan to the court. ${ }^{81}$ For our purposes, the distribution plan is controversial because it drew a line between veterans who were uninjured at the time of settlement, but would manifest injury in 1994 or earlier (entitled to monetary compensation), and veterans who would manifest injury after 1994 (not entitled to monetary compensation). ${ }^{82}$ Because the obligation to adequately represent the class rests on class counsel, he cannot evade responsibility for an inadequate distribution plan by asking the court to craft and impose a plan on the parties. Thus, the fact that class counsel did not draft or endorse the plan in Agent Orange should have no bearing on the argument that veterans who manifested injury after 1994 were inadequately represented. Indeed, one could argue that class counsel's delegation of responsibility to the court was driven by the desire to bring costly litigation to an end and get paid - in other words, neglect based on self-interest.

In the absence of a sound substantive justification for drawing a distinction between class members, class counsel has an obligation to ensure, to the extent practicable, that all the class members he represents are compensated equally for the same injury. ${ }^{83}$ If exposure to Agent Orange was harmful, there was no reason at the time of the settlement to believe that injuries from exposure would not manifest themselves after $1994 .{ }^{84}$ As the district judge himself recognized in the fairness opinion,

diseased and presently healthy veterans at the time of the class judgment." Issacharoff \& Nagareda, supra note 6, at 1688. I have no quarrel with the proposition that Stephenson might appropriately have been resolved on that ground. I simply argue that the inadequacy of the representation in Agent Orange was not limited to the failure to separately represent veterans who were ill from those who were apparently healthy at the time of settlement.

80. As Professor Schuck notes, the

notice of proposed settlement had not contained a distribution plan but had simply outlined the basic elements of the plan the PMC had indicated it would propose, which proposal [Judge] Weinstein subsequently rejected. And it was only in May 1985, more than four months after he had finally approved the settlement, that he issued the plan.

SCHUCK, supra note 79, at 221.

81. In re "Agent Orange" Prod. Liab. Litig., 611 F. Supp. 1396, 1399-1400 (E.D.N.Y. 1985).

82. Id. at $1417-19$.

83. For a discussion of the limits practicality imposes on adequate representation, see supra Part II.A, D-E.

84. I do not suggest that the claims of any of the class members in the Agent Orange litigation were strong at the time settlement was reached. Quite apart from serious questions of causation, the manufacturers of Agent Orange had important defenses available, including the government contractor defense. Indeed, after some plaintiffs successfully mounted a collateral attack on the judgment settling the claims, defendants obtained a dismissal premised on the government contractor 
"[i]t took almost forty years for solid tissue cancer to develop in victims of the atomic bombing in Japan." ${ }^{\text {"5 }}$ Thus, the representation in Agent Orange was inadequate because it permitted the disparate treatment of injured veterans without any substantive justification.

Professors Issacharoff and Nagareda have argued that veterans who suffered injury after 1994 were not disadvantaged because every veteran who was uninjured at the time of settlement received the functional equivalent of an insurance policy covering injuries for the period prescribed by the settlement. ${ }^{86}$ From that perspective, veterans arguably received insurance policies of equal value. I disagree that analogizing the settlement to an insurance policy is the appropriate way of valuing the settlement for the purpose of determining adequate representation. While it was not possible at the time of settlement to predict the benefit of the settlement to any particular class member, it was clear at the time of settlement that some veterans would receive no compensation simply because they would suffer injury after 1994. Thus, it should be of little moment that those who would be denied compensation could not be identified at the time of settlement. ${ }^{87}$ Class counsel had an obligation to take the interests of those veterans into account; the insurance analogy in this context simply disregards those interests. ${ }^{88}$ As the Court in Ortiz noted, treating differently situated class members alike is itself an allocation decision. ${ }^{89}$

defense. See In re "Agent Orange" Prod. Liab. Litig., 517 F.3d 76, $89-92$ (2d Cir. 2008).

85. In re "Agent Orange," 597 F. Supp. 740, 795 (E.D.N.Y. 1984). Cf. Issacharoff \& Nagareda, supra note 6, at 1686 n.117 ("The lapse of time-the ten year cutoff came more than twenty years after the last alleged exposure to Agent Orange-made a causal connection increasingly implausible.") (citation omitted).

86. Issacharoff \& Nagareda, supra note 6, at 1686-87. Professors Issacharoff and Nagareda assume that the only question was how to appropriately allocate the $\$ 180$ million fund set aside to compensate those who manifested injuries compensable under the settlement. But as discussed below, class counsel arguably should have insisted on a larger fund. See infra note 92.

87. Professors Issacharoff and Nagareda cite Uhl v. Thoroughbred Technology \& Telecommunications, Inc., 309 F.3d 978 (7th Cir. 2002), to suggest that the fact that some class members would be paid more than others does not matter for purposes of adequate representation so long as the camp in which a particular class member would fall cannot be determined at the time of settlement. Issacharoff \& Nagareda, supra note 6, at 1689. In Uhl, the same class representative represented class members who would receive very different treatment under the settlement. Uhl, 309 F.3d at 985-86. But unlike the settlement in Agent Orange, there were substantive legal differences between class members in $U h l$ that justified the disparate treatment. Id. at 987 . I do not quarrel with the Seventh Circuit's conclusion - and that of Professors Issacharoff and Nagaredathat separate representation of the differently situated class members in Uhl was unnecessary. See id. at 985-86; Issacharoff \& Nagareda, supra note 6, at 1689-90.

88. David Dana has suggested a number of ways in which the settlement could have been drafted to more fairly protect the interests of those who would suffer injury after 1994. See Dana, supra note 3 , at 327 .

89. Ortiz v. Fibreboard Corp., 527 U.S. 815, 857 (1999). 
I recognize that the conclusion that class counsel neglected the interests of a part of the class out of self-interest is debatable. Indeed, it should be obvious that neglect based on self-interest will often be hard to distinguish from neglect based on lack of diligence; in fact, self-interest may lead to a lack of diligence. ${ }^{90}$ But what matters for present purposes is that, while the neglect that I note does not fit within Aggregate Litigation's definition of "structural defect," neglect in Agent Orange clearly implicates class counsel's duty of loyalty, a matter at the heart of any reasonable definition of adequate representation. Indeed, it makes little sense to ignore the fact that a structural conflict - by any common-sense definition of the terminevitably exists between class counsel and the class. The goal obviously cannot be to eliminate the inherent structural conflict between class counsel and the class, but neither should the consequences of the conflict in particular cases simply be immune from constitutional scrutiny.

In noting that class counsel failed to represent the class with the care and diligence required, I certainly do not suggest that counsel in Agent Orange were incompetent or malicious. But if-as I have arguedcounsel had a duty to protect veterans who would suffer injury after 1994, counsel failed to discharge that duty with reasonable care and due diligence. $^{92}$ It is likely that neither counsel nor Judge Weinstein understood counsel's obligation to those who would manifest injury after 1994. But a mistaken understanding of the requirements of adequate representation cannot immunize the representation from attack if the adequate representation requirement is to achieve its objective.

The Second Circuit applied a different analysis, attempting instead to shoehorn the case into the subclassing analysis set forth in Amchem and Ortiz. ${ }^{93}$ The Second Circuit suggested that veterans who manifested

90. See Restatement (SeCOND) OF Judgments $§ 42 \mathrm{cmt}$. f reporter's note ("While collusion and inadequate diligence or vigor by a representative are logically distinct from conflict of interest on his part, as a practical matter the two will often coalesce."); see also Catherine T. Struve, Commentary on Class Action Settlements Under Attack, 156 U. PA. L. REV. 2143, 2146 (2008) (noting "the difficulty of drawing a bright line between performance defects and structural defects").

91. See supra Part II.C.1.

92. I do not suggest that counsel's failure to protect those who manifested injury after 1994 was the only way in which the representation provided by counsel may have fallen short of the requirements of adequate representation. See, e.g., SCHUCK, supra note 79, at 161 (noting that class counsel was in a poor position to defend a settlement amount higher than $\$ 180$ million because "the lawyers possessed little reliable information either about the number of class members who would actually claim against the settlement fund or about the nature of their specific injuries"). But see id. ("In some ways, the ... lack of information was understandable."). For discussion of the judge's role in artificially limiting the size of the settlement fund, see infra notes 176-80 and accompanying text.

93. Stephenson v. Dow Chemical Co., 273 F.3d 249 (2d Cir. 2001). The Court concluded: 
illness after 1994 received inadequate representation because they were not separately represented from those who manifested illness before 1994. Because subclasses are appropriately drawn before settlement, whether a class suit was properly structured cannot reasonably be determined on the basis of lines drawn by the settlement. ${ }^{94}$ But the Reporters of Aggregate Litigation are mistaken in thinking that, as long as class members adversely affected by the settlement cannot be identified in advance of settlement, the requirements of adequate representation have been served. ${ }^{95}$ That is too simplistic a view, privileging the prophylactic protections of Amchem and Ortiz over a core marker of adequate representation in the context of settlement-a settlement that appropriately takes into account the relative economic value of class members' legal claims.

\section{The BancBoston Litigation}

Hoffman v. BancBoston Mortgage Corp. ${ }^{96}$ even more clearly demonstrates the need for an adequacy standard that goes beyond the narrow definition championed by Aggregate Litigation and Professors Issacharoff and Nagareda. ${ }^{97}$ Class counsel in BancBoston had settled claims against defendants in an Alabama lawsuit alleging that defendants were requiring plaintiff mortgagors to maintain escrow accounts larger than authorized by the mortgage contracts. ${ }^{98}$ The settlement reduced the size of future escrow accounts, required a refund of some of the money

No provision was made for post-1994 claimants, and the settlement fund was permitted to terminate in 1994. Amchem and Ortiz suggest that Stephenson and Isaacson were not adequately represented in the prior Agent Orange litigation. Those cases indicate that a class which purports to represent both present and future claimants may encounter internal conflicts.

Id. at $260-61$.

94. Nagareda, Administering Adequacy, supra note 6, at 319.

95. See AgGREgate Litigation, supra note $8, \S 2.07 \mathrm{cmt}$. d reporters' note ("disapproving" the Second Circuit's argument that "the class due-process violation lay in the conflict between veterans who manifested disease before the cutoff for cash benefits specified by the class settlement and those who manifested disease thereafter - a distinction that did not exist at the time of class certification but, rather, was the creation of the class settlement itself').

96. No. CV-91-1880 (Ala. Cir. Ct. Jan. 24, 1994). Professor Koniak discusses the litigation at length. See Koniak, supra note 3, at 1808-17; Susan P. Koniak \& George M. Cohen, Under Cloak of Settlement, 82 VA. L. REV. 1051, 1058-68 (1996).

97. See Nagareda, Administering Adequacy, supra note 6, at 340 ("The problem in the BancBoston litigation stems not from any misalignment of interest within the class but, instead, from the inherent misalignment of interest between the class and class counsel-here, class counsel's willingness, as part of the class settlement agreement, to embrace a fee calculus that disserved the interests of the class.").

98. State v. Homeside Lending, Inc., 826 A.2d 997, 999 (Vt. 2003). 
held in escrow accounts, and mandated the payment of interest on amounts held in escrow without authorization. ${ }^{99}$ The interest due under the settlement amounted to less than nine dollars on average for existing mortgagors. ${ }^{100}$ Class counsel then sought (and obtained) attorneys' fees that were out of proportion to the benefit conferred on the class. In refusing to give effect to the Alabama judgment, the Vermont Supreme Court quoted the perceptive analysis of Professors Koniak and Cohen:

Class counsel asked for attorney's fees equaling $331 / 3 \%$ of all the money the bank was wrongfully holding in escrow; that is, one-third of all the excessive cushion money .... Had there been no lawsuit, $100 \%$ of the excess cushion would have been returned to class members at the time their mortgages were repaid. Therefore, what the lawsuit recovered for each class member was (in addition to the back interest) only the difference between the value of the excess cushion money in the class member's hands today and the value of the money had the bank held it until the mortgage was paid off.... All that the class members had lost by the bank's allegedly wrongful acts was the use of that money today and the use of that money in years past.

As a result of the formula used to calculate the attorneys' fees, many mortgagors lost money as a result of the settlement. ${ }^{102}$ The most widely known example is that of a class member who recovered \$2.19 in interest, but paid an attorneys' fee of $\$ 91 !^{103}$ Professors Koniak and Cohen note that "[a]ny class member who paid more in attorney's fees than he or she recovered 'would have been better off if class counsel had lost the case." $" 104$

Yet whether class counsel in Alabama acted out of incompetence (a performance defect) or unacceptable greed (the manifestation of a structural conflict), Aggregate Litigation-and Professors Issacharoff and Nagareda - would apparently conclude that the representation in this case (and in Agent Orange) cannot be deemed constitutionally inadequate, no matter how problematic class counsel's conduct. ${ }^{105}$ That

99. Id. at 1000 .

100. Id. at $1001-02$.

101. Id. at 1002-03 (citing Koniak \& Cohen, supra note 96, at 1063).

102. Koniak \& Cohen, supra note 96 , at 1063.

103. Id. at 1067; see also Homeside Lending, 826 A.2d at 1003 (noting the allegations in the complaint (1) that the settlement was of $n o$ benefit to residents of Vermont because Vermont law requires that interest be paid on escrow accounts at the prevailing savings account rate and (2) that residents of Vermont were required to pay at least $\$ 30,000$ in attorneys' fees).

104. Homeside Lending, 826 A.2d at 1003 (quoting Koniak \& Cohen, supra note 96, at 1068).

105. Remarkably, Professors Issacharoff and Nagareda in part appeal to "intuition" to support this conclusion. See Issacharoff \& Nagareda, supra note 6, at 1700 ("There is an intuitive difference, in short, between the existence of legitimate authority to act upon class members on an 
is because the defects in representation manifested in BancBoston and Agent Orange had nothing to do with the "structure of the classes involved," 106 but rather with counsel's performance.

\section{The Epstein Litigation}

It is less clear whether the representation in Epstein v. MCA, Inc., ${ }^{107}$ the landmark case rejecting collateral attack, satisfies the constitutional standard for adequacy endorsed by Professors Issacharoff and Nagareda. In that case, the Ninth Circuit considered whether a class member absent from a Delaware class action could collaterally attack the Delaware judgment in a separate federal class action in California. ${ }^{108}$ The federal action was pending at the time the Delaware state court rendered judgment approving the settlement of (1) state-law claims for breach of fiduciary duty and (2) federal securities claims. ${ }^{109}$ The state court had no subject-matter jurisdiction over the federal securities claims, and the state-law claims were so weak that Judge Norris noted that "it would not be an exaggeration to say that the Delaware plaintiffs were kept in state court entirely at the sufferance of [defendants]." used the state-court action as a way of settling the far stronger federal claims cheaply, knowing that "class counsel had an extraordinary incentive to settle and settle quickly" before judgment could be rendered in the securities class action in federal district court "because that was the only way they could extract a fee out of the federal claims."111

aggregate basis and the proper exercise of that authority in the settlement at hand.").

106. Id. at 1697 (emphasis added).

107. 126 F.3d 1235 (9th Cir. 1997), vacated, 179 F.3d 641 (9th Cir. 1999). For a useful discussion of the Epstein litigation, see Koniak, supra note 3, at 1808-17.

108. Epstein, 126 F.3d at 1242 .

109. Id. at 1235.

110. Id. at 1249 n.13. "[T]he Delaware Vice Chancellor, in rejecting the first settlement, determined that the state law claims were 'extremely weak' and had 'little or no value' because no such state cause of action existed." Id. (citing In re MCA Shareholders Litigation, 598 A.2d 687, 694 (Del. Ch. 1991)). Delaware class counsel did not even conduct discovery on the federal claims and may not have been able to do so "because the facts relevant to those claims had no apparent relevance to the subject matter of the state law claim that the MCA directors had breached their fiduciary duties in failing to maximize shareholder value upon a change of corporate control." Id. at 1249.

111. Id. at 1250. As Judge Norris explained:

Class counsel could not benefit from the federal claims by going to trial for the obvious reason that the federal claims could not be litigated in state court. Moreover, the pendency of a parallel action in federal court-the Epstein case - meant that Delaware class counsel were at risk of being "beaten to the punch" and getting no return on the federal claims at all. Matsushita knew that it was negotiating a release of the federal claims with class counsel who could not litigate those claims and whose self-interest gave 
The "jarring misalignment"112 of interests between class counsel and members of the class led to a classic example of "shirking,"113 a type of misconduct Professors Issacharoff and Nagareda insist is exempt from constitutional scrutiny. ${ }^{114}$ Both Aggregate Litigation and Professors Issacharoff and Nagareda emphasize structural defects that result from conflicts between segments of the class or between the class and others represented by class counsel. ${ }^{115}$ No such conflicts exist in Epstein.

On the other hand, the literal wording of the abstract standard set forth in Section 2.07(a)(1)(A) of Aggregate Litigation is sufficiently broad to justify the conclusion that the representation in Epstein was inadequate. Aggregate Litigation expressly forbids "structural conflicts of interest between the named parties or other claimants and the lawyers who would represent claimants on an aggregate basis."116 Because Delaware had no subject-matter jurisdiction to try the federal claims,

them an incentive to settle and settle fast.

What all this demonstrates is that there was a jarring misalignment of interests between class counsel and members of the federal class. It was plainly in the best interest of counsel to settle the federal claims at any price. For them, any settlement was better than no settlement because settlement was the only way they could make any money on the federal claims - indeed, given that the state claims were essentially worthless, it was the only way that Delaware counsel could get any compensation at all.

Id.

112. Id.

113. Cf. Issacharoff \& Nagareda, supra note 6, at 1657 (distinguishing "structural conflict[s] of interest" from class counsel's decision to "shirk responsibility by accepting an inadequate settlement so as to gain quickly at least some modicum of a fee award from the litigation"). The defects at issue in Epstein involved not the structure of the class, but counsel's self-interested decision to settle the federal claims cheaply. Judge Norris noted a particularly egregious illustration of the lengths to which class counsel were willing to go in shirking their responsibilities:

The inadequacy of Delaware counsel's representation is brought into sharp focus by their vigorous disparagement of the federal claims throughout the course of the settlement proceedings. . . . Counsel consistently sought to convince, not only their clients, but their adversaries and the Chancery Court itself that the federal claims had no merit. They repeatedly and summarily dismissed those claims as "frivolous" without ever conducting any discovery or any meaningful analysis of the legal issues, much less presenting the claims in a favorable light.

Epstein, 126 F.3d at 1251. Even Judge O'Scannlain-who argued against collateral attack-agreed that the representation in question was problematic: "[Counsel's] act of referring, in a single breath, to their own clients' claims as 'fraught with uncertainty,' 'weak,' and 'horrendous' suggests less than dynamic advocacy." Id. at 1256 (O’Scannlain, J., dissenting).

114. Issacharoff \& Nagareda, supra note 6, at 1699-1700 (arguing that shirking by class counsel does not render the representation constitutionally inadequate). Professors Issacharoff and Nagareda note: "The defendant in a reverse-auction scenario plays on this residual risk of shirking by parking a desired class settlement with class counsel most inclined to shirk in exchange for at least some measure of a fee award." Id. at 1699. This appears to describe what defendants did in the Epstein litigation.

115. Id. at 1677-98; see also AgGREGATE LitigAtion, supra note $8, \S 2.07 \mathrm{cmt}$. d.

116. AgGREGAte LitigAtion, supra note $8, \S 2.07(\mathrm{a})(1)(\mathrm{A})$. 
Delaware class counsel was disabled from trying the federal securities claims. ${ }^{117}$ On that basis, it could be argued that any effort by counsel to settle those claims would be infected by a structural conflict under section 2.07(a)(1)(A).

Professor Issacharoff has argued that in addressing a different issue the Court treated "far too lightly the potential consequences of a settlement in which... the lawyers [had] no claim to speak as authoritative agents for the class." 118 But remarkably, both Aggregate Litigation and Class Settlements Under Attack are silent on whether the representation in Epstein would pass constitutional muster under the standard they endorse. In any event, it should make little difference from a constitutional standpoint whether or not the problem in Epstein can be shoehorned into the narrow confines of section 2.07(a)(1)(A). As the Ninth Circuit recognized, the defects in representation in Epstein clearly implicate class counsel's duty of loyalty, a matter at the heart of any reasonable understanding of the constitutional requirements of adequate representation. ${ }^{119}$

In short, Aggregate Litigation's attempt to circumscribe the constitutional meaning of adequate representation to a narrowly defined set of structural conflicts ignores the rationale of the adequaterepresentation requirement in favor of a framework apparently crafted to make finality substantially easier to achieve. I agree that finality is precious, but it should not be purchased at the price of eviscerating the adequate-representation requirement.

\section{The Subclassing Requirement}

In the Subparts above, I demonstrated that the meaning of adequate representation cannot be limited to structural defects as that term is

117. Cf. Issacharoff \& Nagareda, supra note 6, at 1697 (stating that a class suit that does not encompass all of the claimants may create a disabling conflict "because of the structure of the classes involved").

118. Issacharoff, supra note 20, at 389 (criticizing Matsushita Elec. Indust. Co. v. Epstein, 516 U.S. 367 (1996)). The Court in Matsushita held that the judgment at issue in Epstein could not be denied full faith and credit simply because the Delaware courts lacked subject-matter jurisdiction over the federal claims. Id. The Ninth Circuit decisions discussed in the text were rendered on remand.

119. See Epstein v. MCA, Inc., 126 F.3d 1235, 1250-51 (9th Cir. 1997), vacated on other grounds, 179 F.3d 641 (9th Cir. 1999). 
narrowly defined by Professors Issacharoff and Nagareda. In this section, I explain how courts should determine whether subclassing is an appropriate remedy for any given structural conflict within the class.

Amchem and Ortiz require that absent class members with conflicting interests be separately represented through the use of subclasses. Of course, taken to its logical extreme, subclassing would render use of the class device simply impracticable. ${ }^{120}$ But there is no reason to believe that the Court intended to require subclassing beyond the bounds of practicality. The Court's focus in Ortiz was on subclassing with respect to "easily identifiable categories of claimants," 121 and it acknowledged that "at some point there must be an end to reclassification with separate counsel." 122 Put simply, Amchem and Ortiz are best read as creating a rebuttable presumption that easily identifiable categories of claimants should be separately represented by counsel.

The key to appropriately applying the subclassing requirement of Amchem and Ortiz is to recognize that, in class suits seeking money damages, the interests of an absent class member are best served by maximizing his or her recovery. Thus, a district court should not require separate representation of a category of claimants if the cost of separate representation will outweigh the potential benefits to those claimants. ${ }^{123}$ It will often be wasteful to require separate representation of all identifiable categories of claimants in negative-value suits, for example. As the Seventh Circuit reasoned in one such suit:

[I]n light of the modesty of stakes even of class members who had multiple refund anticipation loans and the expense of subdividing the class (and how many subdivisions would be necessary to reflect the full range of damages?), we are not disposed to regard this particular defect in the settlement as fatal. ${ }^{12}$

120. John C. Coffee, Jr., Class Action Accountability: Reconciling Exit, Voice, and Loyalty in Representative Litigation, 100 COLUM. L. REV. 370, 396 (2000) (noting that excessive subclassing "call[s] into question the viability of the class action as an efficient organizational form"); Issacharoff, supra note 20, at 380 (noting that a reading of Amchem that would forbid any allocative decisions by plaintiffs' counsel would require "a spiral of subclasses and sets of counsel that would not only swamp the incentive to invest in bringing a class action, but would impose tremendous transactional costs on an already vulnerable procedure that turned heavily on its ability to realize economies of scale").

121. Ortiz v. Fibreboard Corp., 527 U.S. 815, 831-32 (1999) (emphasis added).

122. Id. at 857 .

123. In calculating the "cost" of representation, the court must include compensation sufficient to persuade skilled counsel to invest appropriate time and resources in the litigation.

124. Reynolds v. Beneficial Nat'l Bank, 288 F.3d 277, 282 (7th Cir. 2002). 
And even in high-value suits, at some point in the subdivision of the class, the potential expense of providing separate representation will not be commensurate with the potential benefit to those separately represented. ${ }^{125}$ In short, in deciding whether a particular category of claimants should be afforded separate representation, a court must consider whether the conflict of interest is of such magnitude as to lead to the conclusion that a category of claimants would benefit from separate representation.

The use of subclassing may also be impracticable from the standpoint of managing the class suit as a whole. In such a case, adequate representation will not require further subclassing if it is in the interest of all class members to proceed in a single suit. In other cases, for at least some class members, the benefits of being part of the class suit will not outweigh the costs resulting from a lack of separate representation. The court in such a case ordinarily should order that the claims of such class members be severed from the larger class suit.

Because the requirement of separate representation for divergent interests must be limited by practical considerations, there may well be conflicts of interest within a subclass. ${ }^{126}$ While the zeal with which class counsel represents any individual member must be tempered by counsel's responsibility to the subclass as a whole, each class member in the subclass has the right to expect that class counsel will competently endeavor to treat the class member's claims equitably vis-à-vis the claims of others that counsel represents.

In a recent article, Jay Tidmarsh has argued that adequate representation, properly understood, does not require subclassing at all ${ }^{127}$ - that an individual has been adequately represented in a class suit provided that he or she would be no worse off proceeding in a class suit than he or she would have been in individual litigation. ${ }^{128}$ There is much

125. Charles Silver \& Lynn Baker, I Cut, You Choose: The Role of Plaintiffs' Counsel in Allocating Settlement Proceeds, 84 VA. L. REV. 1465, 1497 (1998) ("“I]n the real world, members of litigation groups often view conflict-related risks as a price they are willing to pay to obtain large and certain economic benefits, including economies of scale and the strategic advantage of presenting a united front." (footnotes omitted)).

126. See id. at 1496 ("If the Due Process Clause absolutely prohibits counsel for a group from resolving conflicts among claimants, each class member must be separately represented on the matter of settlement allocation."); Issacharoff, supra note 20, at 385 (noting that "[s]ome allocation decisions are inescapable because there is an inevitable rough-hewn quality to the relief provided by class actions").

127. Jay Tidmarsh, Rethinking Adequacy of Representation, 87 TEX. L. REV. 1137, 1139 (2009). Professor Tidmarsh finds subclassing "wanting" as a technique to address conflicts within the class. Id. at 1199 n.262; see also id. at 1162-64.

128. Id. at 1139 ("Representation by class representatives and counsel is adequate if, and only if, the representation makes class members no worse off than they would have been if they had engaged 
to be said for Professor Tidmarsh's approach, which he calls the "'do no harm' principle." "129 His focus on the bottom line for the individual after fees and costs tracks with my argument that adequate representation in class suits for money damages is essentially about safeguarding the economic value of individual claims. He also recognizes that the cost of litigation must be factored into any assessment of adequate representation. $^{130}$

Our views differ in two noteworthy respects. First, while I agree that the settlement value of a case (and the claims therein) must be considered in analyzing adequacy, ${ }^{131} \mathrm{I}$ am skeptical of the view that adequate representation can be reduced to settlement value. As Donald Puckett has observed:

The extent and value of the plaintiffs' injuries are likely to be the subject of intense factual dispute, with estimates possibly differing by thousands or millions of dollars. The likelihood of success on the merits is also likely to be disputed on both factual and legal grounds, with difficult issues of duty and causation or contract interpretation and the like complicating any inquiry into the plaintiffs' chances of winning or losing. Perhaps the additional legal expenses are slightly more capable of calculation, but uncertainties regarding the extent of preparation necessary and the duration of litigation also make this variable less than precise. ${ }^{132}$

in individual litigation."). But see id. at n.16 (noting that the formulation is too simplistic with respect to negative-value suits). Professor Tidmarsh puts his understanding of the adequate representation requirement in the following mathematical form: $\left(P_{I} * L_{I}\right)-\left(F_{I}+C_{I}\right)<\left(P_{C} * L_{C}\right)-$ $\left.\left(F_{C}+C_{C}\right)\right) . I d$. at 1177

$P_{I} \ldots$ represent $[\mathrm{s}]$ that probability of a class member's recovery in individual litigation, $L_{I}$ the size of the recovery in individual litigation, $F_{I}$ the attorneys fees in individual litigation, and $C_{I}$ the costs of individual litigation. And let $P_{C}$ represent that probability of a class member's recovery in class litigation, $L_{C}$ the size of the recovery in class litigation, $F_{C}$ the member's pro rata share of attorneys fees in class litigation, and $C_{C}$ the member's pro rata share of costs in class litigation.

$I d$. at 1176-77. For a full description of the proposal, see $i d$. at 1176-80.

129. Id. at 1177.

130. Supra note 128 (particularly variable $C_{I}$ ).

131. See, e.g., Reynolds v. Beneficial Nat'l Bank, 288 F.3d 277, 285 (7th Cir. 2002) (recognizing that "[a] high degree of precision cannot be expected in valuing a litigation, especially regarding the estimation of the probability of particular outcomes," but insisting that "much more could have been done here without (what is obviously to be avoided) turning the fairness hearing into a trial of the merits"); see also Dana, supra note 3, at 281 ("[A]lthough the adequacy of representation inquiry certainly entails an examination into the presettlement structure of representation and the content of the proceedings, the inquiry also has, or at least should have, something to do with ex post substantive outcomes-about what the settlement actually delivers in the way of relief to individual class members.").

132. G. Donald Puckett, Peering into a Black Box: Discovery and Adequate Attorney Representation for Class Action Settlements, 77 TEX. L. REV. 1271, 1280 (1999) (noting that "each 
Professor Tidmarsh avoids many of the difficulties of calculation by defining adequate representation to mean that a class member must be no worse off in the class than he or she would be in individual litigation, a standard that may necessitate only the roughest ballpark estimates. ${ }^{133}$ But as I note immediately below, I do not think the definition he suggests is sufficiently protective of the claims of class members. Because of the difficulty of accurately gauging settlement value, I doubt that the constitutional right to adequate representation can be properly safeguarded by focusing solely on the value of the settlement.

Second, I believe adequate representation requires an effort by counsel and the class court to distribute settlement proceeds (less reasonable attorneys' fees and costs) in accordance with the relative strength of class members' claims, unless - and only to the extent thatproviding a greater level of precision would not be worth the cost of doing so. By contrast, the disposition of settlement proceeds under Professor Tidmarsh's model is irrelevant, provided each class member is no worse off than he or she would be in individual litigation. ${ }^{134}$ In short, rather than requiring an equitable distribution of settlement proceeds, Professor Tidmarsh would leave distribution of any surplus created by the class device free from constitutional constraints. ${ }^{135}$ In my view, that wide discretion-while administratively appealing ${ }^{136}$ - does not

of the variables" used to calculate settlement value "is incapable of precise measurement" and arguing that "[a] judicial assessment of settlement value fails to identify unfair settlements"); see also Geoffrey C. Hazard, Jr., Lecture, The Settlement Black Box, 75 B.U. L. REV. 1257, 1266 (1995) ("[T]he objective value of a settlement is indicative of unfairness in a settlement only in outrageously bad settlements."). The difficulty of precisely calculating settlement value does not mean that settlement value should be ignored altogether in determining adequacy.

133. See Tidmarsh, supra note 127, at 1189 (conceding "that precise measurements under the 'do no harm' formula are difficult to make," but arguing that "it is unlikely that such detailed calculations will be necessary").

134. See id. at 1191 ("Because the remaining class members are no worse off than they would have been with individual control..., the representation in this case is, under the 'do no harm' principle, adequate.").

135. Id. (noting that the "do-no-harm" principle "is a minimal principle, rather than a maximal version of adequacy that requires the gains from class treatment to be distributed among claimants in proportion to the strength and extent of their claims ...."). Professor Tidmarsh nonetheless argues that "[r]eal-world dynamics temper the inequities inherent in the 'do no harm' principle and push the parties toward the 'equal gains for equal claims' principle without incurring the added costs of adopting the latter principle across the board." Id. at 1192.

136. Professor Tidmarsh notes:

Despite its surface appeal, one problem with an "equal gains for equal claims" principle is the difficulty of applying it in many class actions. When class members present an array of temporally and geographically dispersed claims and injuries, an "equal gains for equal claims" principle requires the collection of a great deal of information, as well as difficult judgments about which claims, claimants, and distributions are in fact "equal." Such a principle would therefore eat deeply into-and perhaps surpass - the gains in reduced litigation costs and avoidance of harms that are the 
sufficiently respect the property interests of individual class members. The property right at issue is not a right to individual litigation, but to the remedy afforded by law. The cost of litigation must be included when calculating the economic value of a claim. But focusing on the cost of individual litigation when claims are being litigated through the class device does not give sufficient weight to the remedy provided by law.

Subclassing is an important tool if adequate representation requires that the relative strength of class member claims be taken into account in dividing up settlement proceeds. Counsel for a subclass will have an incentive to unearth evidence and make arguments that would support a higher valuation for the claims of class members he represents vis-à-vis the claims of other class members. In other words, subclassing may provide a net benefit to a subclass that would outweigh the costs of separate representation. Given the high cost of separate representation, subclasses should be used sparingly, but should be used when appropriate.

\section{E. The Nature of Adequacy Review}

A reviewing court — on direct or collateral review — should keep in mind that class counsel and the class court often make difficult judgment calls. To reject a reasonable judgment by the class court or class counsel simply because a reviewing court would have made a different judgment would fail to give finality its due. For that reason, so long as the class court has applied the appropriate legal criteria, its decisions with respect to subclasses should withstand review, unless the court acted unreasonably or there is an appropriate basis for challenging the record on which the decision was made. Similarly, class counsel should not be found to have provided inadequate representation unless a reasonable lawyer - with a proper understanding of his legal obligations to the class - would have acted differently. ${ }^{137}$

raison d'être of Rule 23.

Id. (citation omitted). I agree that the "equal gains for equal claims" principle may have to give way for practical reasons, but only on a case-by-case basis.

137. See Woolley, Choice of Law, supra note 16, at 827-28 (calling for a "reasonable lawyer" standard of adequacy and noting that "[b]ecause assessment of litigation risks and tradeoffs is not an exact science, a reasonable lawyer standard would give class counsel significant discretion"). Professor Rubenstein has argued that on collateral attack, counsel's performance must have "prejudiced" absent class members. Rubenstein, supra note 1, at 863. To the extent a collateral attack is premised on class counsel's performance, prejudice may be an appropriate part of the inquiry. I do not address that issue in this Article. 
Appellate courts have long applied an abuse of discretion standard in reviewing whether representation of the class has been adequate. ${ }^{138}$ Review on collateral attack, by contrast, should be de novo. ${ }^{139}$ If the class court lacked the power to require the absent class member to appear, the absentee cannot properly be bound by the record developed in the class court. ${ }^{140}$ I do not mean that on collateral review an absent class member may introduce any admissible evidence that in hindsight tends to show that the class member was inadequately represented. Because the question is whether the absentee received adequate representation at the time of the original lawsuit, ${ }^{141}$ the only information going to the strength of class claims that is relevant on collateral review is that which could have been uncovered with reasonable diligence on the part of the class court and class counsel. If there is no basis for supplementing the record with additional information, the task of a court

138. See Woolley, supra note 3 , at $436 \&$ n.235 (collecting authority and noting that "the weight of precedent indicates that courts of appeal should apply an 'abuse of discretion' standard"). I nonetheless believe that whether class counsel acted reasonably should be assessed de novo on direct review. See note 137 and accompanying text. A court on direct review applying a de novo standard remains bound by the trial court's findings of historical fact. Woolley, supra note 3 , at 437 .

139. See id. at $436 \&$ n.234 (collecting authority). Professor Rubenstein has noted that none of the cases I cite "actually say that this is the governing standard - they just use it." Rubenstein, supra note 1 , at $814 \mathrm{n} .95$.

140. As Professor Koniak has recognized:

The court in which the challenge is brought must review adequacy de novo to avoid binding the challenger to any part of a judgment (or settlement) until that court determines that the first court had the power to affect the rights of the challenger. Any lesser standard of review would be incoherent.

Koniak, supra note 3, at 1836-37.

141. As Professor Rubenstein notes:

F2 might inquire whether, knowing what we knew at the moment of settlement, was F1 correct that the class was adequately represented? But of course, F2 is tempted to ask something quite different. Since time has passed-fifteen years in Stephenson-F2 is enticed to pose the question, knowing what we know now, was the class adequately represented? When F2 asks this question, it is not truly revisiting the wisdom of F1's adequacy determination. It is remaking that decision in light of subsequent developments and/or changed circumstances.

Rubenstein, supra note 1, at 813 . F1 and F2, of course, are terms used in preclusion law to refer respectively to (1) the forum which renders the original judgment and (2) the forum which determines the preclusive effect of the judgment rendered in F1.

I recognize that even if the inquiry is properly framed, the risk of hindsight bias highlighted by Professor Rubenstein remains. See id. at 839 (arguing that the collateral court has a "tendency to fall victim to "hindsight bias"). "Hindsight bias "occurs when a person who knows how a risk actually played out is asked to "go back in time" and estimate the ex ante likelihood that the observed outcome would occur."' Id. at n.183 (quoting Charles M. Silver, Dissent from Recommendation to Set Fees Ex Post, 25 Rev. LiTig. 497, 498 n.3 (2006)). The risk of hindsight bias should be minimal in cases in which the statute of limitations on the underlying claims runs within a few years of the class judgment. In any event, while the concerns raised by Professor Rubenstein are real, those concerns cannot be allowed to trump constitutional rights. 
on collateral review should be the same as on direct review. ${ }^{142}$ But if new information is presented on collateral review, the task of the court is different. The court must ask whether a finding of adequate representation is appropriate on the enhanced record.

\section{COLLATERAL ATTACK}

In the previous part, I explained why the cramped understanding of the constitutional demands of adequate representation proffered by the Reporters is wrong and offered a model that attempts to reconcile the demands of fairness to absent class members with the need for finality. In this part, I address whether a proper understanding of governing procedural principles permits the sort of limits on collateral attack that Professors Issacharoff and Nagareda call for in their scholarly work and in Aggregate Litigation. ${ }^{143}$ Specifically, Professors Issacharoff and Nagareda argue that (1) collateral attacks should address only structural defects, (2) collateral attacks should be unavailing so long as the court rendering the judgment has ruled on the structural defect in question, and (3) personal-jurisdiction requirements pose no obstacle to limiting collateral attacks. There is no basis for limiting collateral attacks to structural defects; as argued above, structural defects and performance defects are equally serious from a constitutional perspective. ${ }^{144}$ I address below the remaining two arguments for limiting collateral attack and conclude that they have no sound basis in law.

Professors Issacharoff and Nagareda would frame the debate over collateral attacks "as part of an unresolved conflict between the individualist premise of our inherited tradition of civil litigation and the reality of circumscribed litigant autonomy in aggregate litigation, most notably class actions." 145 But the frame they select is inexact at best. The debate over collateral attack is more properly framed as whether individuals are to be permitted to insist on enforcement of the very guarantee that justifies circumscribing litigant autonomy in the first place.

142. See supra notes $137-39$ and the accompanying text (discussing standards of review).

143. The Reporters insist that other remedies for inadequate representation may be available, including actions for malpractice. AGGREGATE LITIGATION § 3.14; see also Issacharoff \& Nagareda, supra note 6 , at 1712 . I have previously explained why malpractice actions are not a constitutionally acceptable substitute for collateral attacks. See Woolley, supra note 3, at 428-32.

144. Supra Parts II.A-C.

145. Issacharoff \& Nagareda, supra note 6, at 1654. 


\section{A. The Nature of a Collateral Attack on a Class Judgment}

As a general rule, a party is bound by a judgment unless that judgment is reversed on direct appeal. A plaintiff cannot bring a new suit on the same claim in a different court because he or she is unhappy with the judgment, and a defendant cannot argue that the judgment was wrong if suit is brought to enforce the judgment. So provides the law of res judicata. There can be no doubt that the principles of res judicata similarly bar relitigation by an absent class member who was adequately represented and who waived any right to "be heard and participate in the litigation." $" 146$

But while direct appeal ordinarily is the only avenue available to review a judgment, the law has long recognized that a collateral attack on a judgment may be appropriate in limited circumstances. ${ }^{147}$ For example, when a defendant in ordinary litigation fails to appear in court and that court lacks personal jurisdiction over the defendant, the law is clear that the defendant can defend against enforcement of a default judgment on the ground that the F1 court lacked personal jurisdiction. ${ }^{148}$ The availability of collateral attack in these circumstances remains unquestioned even though courts of appeal have held that the F1 court has an obligation to determine whether it has personal jurisdiction over the defendant. ${ }^{149}$ The law traditionally has also recognized the right of an absent class member to collaterally attack a judgment for inadequate representation. ${ }^{150}$

146. Phillips Petroleum Co. v. Shutts, 472 U.S. 797, 812 (1985).

147. What distinguishes a direct attack from a collateral attack is that a direct attack involves an appeal of the judgment while a collateral attack challenges the res judicata effect of the judgment, typically through a separate suit. Because motions for relief from a void judgment raise virtually the same issues as more clear-cut examples of collateral attack, I treat such motions as collateral attacks. See Woolley, supra note 3, at 389 n.17. I have argued that the class judge should be disqualified from hearing a motion for relief from judgment based on inadequate representation. Id. at $434 \mathrm{n} .225$ ("Because a finding of inadequate representation after completion of the class proceedings may reflect on the class judge (who had an obligation to monitor the adequacy of the representation throughout the proceeds), that judge should not hear the motion for relief.").

148. See Insurance Corp. of Ireland, Ltd. v. Compagnie des Bauxites de Guinée, 456 U.S. 694, 706 (1982) ("A defendant is always free to ignore the judicial proceedings, risk a default judgment, and then challenge the judgment on jurisdictional grounds in a collateral proceeding."); see also Eugene F. Scoles et Al., Conflict of Laws 332 (4th ed. 2004). By contrast, if the defendant appears, any judicial findings with respect to personal jurisdiction are entitled to preclusive effect and the defense is waived if not raised. $I d$.

149. See, e.g., System Pipe \& Supply Co. v. M/V Victor Kurnatovskiy, 242 F.3d 322, 325 (5th Cir. 2001) (agreeing with the Ninth and Tenth Circuits that "when entry of default is sought against a party who has failed to plead or otherwise defend, the district court has an affirmative duty to look into its jurisdiction both over the subject matter and the parties").

150. See supra notes $2-4$ and accompanying text. 
A collateral attack on a class judgment typically occurs when a plaintiff - an absentee in the earlier class suit ${ }^{151}$ - brings a subsequent suit on a claim within the alleged scope of the class judgment. ${ }^{152}$ The defendant, of course, may defend by pleading preclusion. The plaintiff, for her part, may seek to overcome the preclusion defense by arguing that she was inadequately represented. In short, a collateral attack on a class judgment for inadequate representation, as a conceptual matter, is ordinarily an affirmative defense to the affirmative defense of preclusion. ${ }^{153}$ The plaintiff has a right to litigate the adequacy issue on its merits unless (1) the plaintiff through issue preclusion is bound by the finding of the rendering court that he or she was adequately represented, or (2) the plaintiff by his or her absence in the class proceeding waived his or her adequacy objections.

Professors Issacharoff and Nagareda claim that some courts have invoked claim preclusion as a basis for refusing to permit an absent class member to litigate the adequacy of representation in a second suit:

Some judges urge the application of claim preclusion principles, asking whether the collateral attack plaintiff had a "full and fair opportunity" to raise the alleged constitutional defect in the class-settlement court. Others point to issue preclusion principles, asking whether the asserted defect was actually litigated in and determined by the rendering court.

151. There is general agreement that a class member who appeared in the class suit cannot collaterally attack the judgment for inadequate representation. See Woolley, supra note 3, at 389 ("It is generally accepted ... that a class member who litigates the adequacy issue in the class suit itself is bound by the court's findings on the issue."). But see Rubenstein, supra note 1, at 868 (arguing that collateral attacks should be limited to class members who appeared and protested adequacy in the class suit itself unless they can demonstrate lack of notice or insufficient contacts); Kahan \& Silberman, The Inadequate Search, supra note 5, at 788 (arguing that a "limited form of collateral attack should be available even to those plaintiffs who objected to the adequacy of representation in the first proceeding and were unsuccessful").

152. Aggregate Litigation states that motions for relief from a class judgment are proper under Federal Rule of Civil Procedure 60(b), but insists that inadequate representation is not a basis for relief under Rule 60. AGGREGATE Litigation, supra note $8, \S 3.14 \mathrm{cmt}$. a ("This section does not approve of postjudgment challenge as a vehicle for relitigating findings of adequacy of representation that were made prior to judgment by the court approving the settlement.").

153. There are other contexts in which a plaintiff may assert an affirmative defense to a defendant's affirmative defense. See, e.g., Employer's Mut. Cas. Co. v. Collins \& Aikman Floorcoverings, Inc., 422 F.3d 776, 779 (8th Cir. 2005) (stating that the statute of limitations under Iowa law may be tolled if the plaintiff proves fraudulent concealment); see also Traylor v. Black, Sivalls \& Bryson, Inc., 189 F.2d 213, 217 (8th Cir. 1951) (recognizing that "no reply is necessary in order for the trial court - and this court on appeal- to consider, in like manner and with like effect as if they had been pleaded, any matters which appropriately support a denial or plea in avoidance of the defenses raised in the answer") (emphasis added). As Professor Rubenstein has noted, the burden of proof on collateral attack with respect to inadequate representation is unclear. Rubenstein, supra note 1, at 815-16. I do not purport to resolve the issue here. I note simply that because adequate representation is a jurisdictional issue, it might well make sense to treat adequate representation like other jurisdictional issues on collateral review. 
Still others advocate no preclusion, positing that the collateral-attack court should determine the constitutional question de novo. ${ }^{154}$

But the notion that claim preclusion provides a basis for refusing to permit an absent class member to challenge adequacy of representation obscures what is going on in these cases. If the F2 court concludes that (1) the finding of the class court on adequacy is entitled to issuepreclusive effect or (2) the absent class member waived his adequacy objection by not raising it in the class court, the class judgment may be entitled to claim-preclusive effect. But claim preclusion cannot bar an absent class member from arguing that he or she has been inadequately represented because the question of adequate representation is separate and distinct from the claim that is barred or merged into the judgment. ${ }^{155}$ The requirement that a litigant have a "full and fair opportunity" to make his or her case is a basic requirement of due process, applicable, to be sure - but not limited to - the law of claim preclusion. ${ }^{156}$ Courts that stress that absent class members had a "full and fair opportunity" to raise alleged defects of representation in the rendering court are best understood as making an argument that absent class members-by failing to take advantage of a full and fair opportunity to object in the class proceedings - have waived their right to object to the quality of representation that they received in the rendering court.

Waiver is a legitimate basis for barring collateral attacks for inadequate representation, provided constitutional limits on waiver are respected. Put simply, a failure to contest the adequacy of representation in a class suit can be treated as a waiver only if the court that entered the adequacy findings had authority to compel the absent class member to appear in the litigation for the purpose of contesting the adequacy of

154. Issacharoff \& Nagareda, supra note 6, at 1652-53 (citations omitted).

155. See Restatement (SECOND) JudGMENTS, $\S 24 \mathrm{cmt}$. a (1982) (noting that the Restatement defines the "claim to embrace all the remedial rights of the plaintiff against the defendant growing out of the relevant transaction (or series of connected transactions)"). The Second Restatement also provides: "In an action upon the judgment, the defendant cannot avail himself of defenses he might have interposed, or did interpose, in the first action." Id. $\S 18(2)$. Defense preclusion is equally unavailable because inadequate representation is not a defense to a claim asserted in a class action. In addressing notice and personal jurisdiction objections in ordinary litigation, the Second Restatement of Judgments recognized in any event that "[a]s a conceptual matter, the preclusive effect accorded the determination can best be considered as one of issue preclusion . . . although it is possible to think of it as one of the defensive matters that is foreclosed by the rule of merger." Id. $\S$ $10 \mathrm{cmt}$. d.

156. See, e.g., Kremer v. Chem. Constr. Corp., 456 U.S. 461, 480-81 (1982) ("We have previously recognized that the judicially created doctrine of collateral estoppel does not apply when the party against whom the earlier decision is asserted did not have a 'full and fair opportunity' to litigate the claim or issue." (citations omitted)). 
representation and exercised that authority. As I explain below in Subpart C, the question is essentially one of personal jurisdiction. Thus, if an absent class member is amenable to the personal jurisdiction of the rendering court and the court has authority to require - and requiresthose within its jurisdiction to appear for purposes of litigating adequacy, the court may treat a failure to appear as a waiver of any objections to the adequacy of representation.

By contrast, courts that focus on whether an asserted defect in representation was "actually litigated and determined" are applying issue preclusion to the question of adequacy. Because absent class members were not actually present when the issue was litigated and determined, however, issue preclusion cannot be applied without considering the availability of issue preclusion against absentees. I address the soundness of arguments seeking to apply issue preclusion to absent class members in the next subpart.

\section{B. The Use of Issue Preclusion to Bar Collateral Attacks by Absentees}

Section 3.14 of Aggregate Litigation provides that a class action judgment cannot be challenged unless, among other things, the class court "failed to make the necessary findings of adequate representation." 157 Aggregate Litigation is silent on how detailed the "necessary findings" must be and whether the finding must be the product of an adversarial proceeding. The ambiguity of Aggregate Litigation on this point leaves open the possibility that Aggregate Litigation might be read as authorizing preclusion on the basis of pro forma findings rendered without adversarial proceedings. But Professors Issacharoff and Nagareda are far more specific in their joint article. They argue that detailed judicial findings with respect to adequacy should be given preclusive effect, even in the absence of an adversarial proceeding. ${ }^{158}$ I critique their argument below.

\footnotetext{
157. AgGRegate Litigation, supra note $8, \S 3.14(\mathrm{a})(2)$.

158. See Issacharoff \& Nagareda, supra note 6, at 1716-18. They explain:

A determination, on our account, means a reasoned determination, not a passing, boilerplate dismissal of the structural objection or an unspecific assertion about the absence of any structural defect in the class representation. Rather, the court must articulate the alleged defect and explain why it is not disabling. Id. at 1717.
} 


\section{Virtual Representation}

Unless the law of preclusion is to be radically rewritten, as Professors Issacharoff and Nagareda suggest, ${ }^{159}$ preclusion cannot rest solely on the fact that a court has determined the issue. Absentees ordinarily cannot be bound by judgments rendered in their absence. Rather, the argument must rest on the premise that an absent class member can be bound through representation to the adequacy findings of a class court.

I am deeply skeptical of the contention that a class member can be bound by adequacy findings provided the class member was adequately represented in hearings about the adequacy of class representation. As I have argued elsewhere, an individual should not be forced to accept a representative on the issue of adequacy of representation. ${ }^{160}$ The Second Restatement of Judgments for its part has also recognized that absent class members are entitled to an opportunity to be heard on the question of adequacy. ${ }^{161}$ But as I demonstrate below, even if one assumes that compelled representation is acceptable in this context, current class action practice for handling objections to adequacy does not satisfy the stringent requirements for representation set forth by the Supreme Court.

There is nonetheless scattered support in the lower courts for the view that an absent class member can be bound through representation to the adequacy findings of a class court. The most prominent such decision is that of the Second Circuit in Wolfert. ${ }^{162}$ The court in that case rejected the view that an absent class member with notice could be required to raise his adequacy objections in the class proceeding, ${ }^{163}$ but asserted:

[I]f, in the class action, a defendant opposing class certification or an objector to the settlement had made a serious argument that a sub-class was required because of claims substantially similar to hers, and that

159. Id. at $1715-17$.

160. See Woolley, supra note 3, at 414-15 (arguing that a class member cannot be bound by a representative on the question of adequacy without her consent).

161. See Restatement (SECOND) OF JudGMENTS $\S 42 \mathrm{cmt}$. a (1982) ("It must be recognized, however, that the adequacy of the representation can be established in the action itself only with respect to such of the represented persons who have had opportunity to be heard on the representation question. As to others, the question can be concluded only if and when a person allegedly represented challenges the judgment's effect on him.") The Second Restatement also recognizes (in comment b) that no negative consequences should be attached to the failure of an absent class member to take advantage of an opportunity to be heard on adequacy. See supra note 9.

162. Wolfert ex rel. Estate of Wolfert v. Transamerica Home First, Inc., 439 F.3d 165, 172 (2d Cir. 2006).

163. Id. at $170-71$. 
argument had been considered and rejected by the class action court, it would not be unfair to preclude collateral review of that ruling ....

Judge Wiggins, writing for himself in Epstein v. $M C A$-the landmark case rejecting collateral attack-similarly refused to permit a collateral attack by absent class members on the ground that "the adequacy of representation issue was fully and fairly litigated and necessarily decided in the Chancery Court." 165

But neither the Second Circuit's decision in Wolfert, nor Judge Wiggins' opinion in Epstein, is consistent with the Supreme Court's more recent decision in Taylor $v$. Sturgell rejecting the doctrine of virtual representation. As the Court recognized in Taylor, representatives in our judicial tradition have been allowed to represent others without their consent only in very limited circumstances. ${ }^{166}$ And with only a couple of exceptions - most notably the ability of a designated and adequate class representative to bind absentees - the use of representation has been highly controversial in the absence of a preexisting relationship grounded in the substantive law. ${ }^{167}$ The notion that defendants (as Wolfert suggests) - defendants! - or self-selected objectors with no fiduciary obligation to the class could bind absent class members appears flatly inconsistent with basic principles of preclusion.

Taylor makes clear that, at a minimum, (1) the interests of the "representative objector" and those who are represented would have to be appropriately aligned and (2) the representative objector would have to accept responsibility for acting on behalf of all objectors or the court would have to take steps to protect those represented. Serious questions can be raised about whether the requirements of adequate representation in this context can be met without certification of a "class" of objectors or some similar procedure. ${ }^{168}$ I doubt the practicality of implementing

164. Id. at 172 .

165. Epstein v. MCA, Inc., 179 F.3d 641, 651 (9th Cir. 1999) (Wiggins, J., concurring). Significantly, Judge O'Scannlain, who announced the panel's decision, declined to rely on a virtual representation theory. Id. at 642 (opinion by O'Scannlain, J.).

166. Taylor v. Sturgell, 128 S. Ct. 2161, 2172-73 (2008).

167. As Aggregate Litigation notes in a passage that predates Taylor:

The leading procedural treatise views the general theory of virtual representation with suspicion and cautions against it .... The treatise points out that "class action procedure provides many explicit safeguards designed to ensure adequate representation" and that [v]irtual-representation-theory," by contrast, "has no explicit safeguards." Other commentators agree.

AGGREGATE LitigATION, supra note $8, \S 1.05 \mathrm{cmt}$. a reporters' note (citing WRIGHT ET AL., supra note 3, at $§ 4457$ ); see also Tice v. Am. Airlines Inc., 162 F.3d 966, 968-73 (7th Cir. 1998).

168. I believe the law on this point was clear even before Taylor. See Woolley, supra note 3, at $413-14$. 
class certification requirements (or their functional equivalent) in the context of fairness hearings. And even if it were practical to comply with the requirements of Taylor in this context, a collateral attack on the representation provided by the representative objector should still be available. In short, the theoretical and practical problems posed by a "representative objector" approach are formidable.

\section{The Role of the Court}

Professors Issacharoff and Nagareda bluntly argue that collateral attack should be available only to the extent that grounds for the challenge have not already specifically been addressed by a court. As they explain:

[W] hat should matter for a collateral attack is the rigor of the rendering court's determination of the structural question, not necessarily whether the question has been "actually litigated" by someone in the familiar, adversarial litigation sense....

... A determination, on our account, means a reasoned determination, not a passing, boilerplate dismissal of the structural objection or an unspecific assertion about the absence of any structural defect in the class representation. Rather, the court must articulate the alleged defect and explain why it is not disabling. ${ }^{16}$

169. Issacharoff \& Nagreda, supra note 6, at 1716-17. Professors Issacharoff and Nagareda recognize that their approach would require "relaxation" of the notion of "party" status and argue that the Supreme Court's decision in Devlin v. Scardelletti may "show the way." Id. at 1716 (citing Devlin v. Scardelletti, 536 U.S. 1 (2005)); see also id. at 1708-09. Professors Issacharoff and Nagareda's reliance on Devlin is puzzling. The Devlin Court sensibly held that a class member who objects to the settlement during the fairness hearings need not intervene for purposes of appealing the class judgment; such a class member will be treated as a "party" for purposes of appeal. Devlin, 536 U.S. at 7. Devlin notes that the definition of a "party" may vary depending on the policies underlying a particular area of law. Id. at 7-8. But Devlin is not in tension with Hansberry's insistence that fundamental policies rooted in the Due Process Clause require adequate representation in fact before an absent class member may be treated as a "party" to a class judgment for purposes of preclusion. Hansberry v. Lee, 311 U.S. 32, $42-43$ (1940) ("It is familiar doctrine of the federal courts that members of a class not present as parties to the litigation may be bound by the judgment where they are in fact adequately represented by parties who are present...."). It is true that the Court in Devlin stated that "in light of the fact that petitioner had no ability to opt out of the settlement, appealing the approval of the settlement was petitioner's only means of protecting himself from being bound by a disposition of his rights he finds unacceptable . . . " 536 U.S. at 1011 (emphasis added). But the petitioner in Devlin made an appearance in the litigation by objecting to the settlement in a fairness hearing. Id. at 3-5. Devlin has no bearing on the rights of absent class members who have been inadequately represented. $C f$. AGGREGATE LiTigation, $\S 3.14 \mathrm{cmt}$. a reporters' notes (misquoting Devlin by suggesting that "appealing the approval of the settlement is [a class member's] only means of protecting himself from being bound. ..."). 
They insist that limiting collateral review to arguments not addressed by the class court will create "an incentive for settling counsel to build a body of evidence to elicit and support the rendering court's determination of structural defects with the potential to form the grounds for collateral attack." ${ }^{\prime 70}$ But even granting that settling counsel will have an incentive to build a rich record on the question of adequacy, ${ }^{171}$ their approach is highly problematic. The argument that what truly matters is a reasoned determination by a court-rather than the presence of the affected party or his representative-has never been accepted by the Court outside the limited context of stare decisis. ${ }^{172}$

Professors Issacharoff and Nagareda argue that a reasoned determination by the judge supervising the class suit is sufficient because the judge has a fiduciary responsibility to the class. ${ }^{173}$ There can be no question that courts share responsibility for assuring adequate representation. ${ }^{174}$ But as the literature has shown, judges conducting class actions - as well as class counsel - have structural conflicts with the class. ${ }^{175}$ Moreover, it seems obvious that competent counsel for an objector would be in a better position to advance the interests of the

170. Issacharoff \& Nagareda, supra note 6 , at 1718. The emphasis that Professors Issacharoff and Nagareda place on creating incentives for counsel to create a rich record on the adequacy of the settlement and on requiring the class court to provide a reasoned determination of the adequacy issue addresses some of the objections to reliance on the trial court's decision-making. See Woolley, supra note 3, at 412 (stating that trial courts may "lack information to make an informed evaluation of the fairness of the settlement" and, in any event, are disinclined to rigorously evaluate a settlement (quoting Macey \& Miller, supra note 20, at 45-47)).

171. But see Struve, supra note 90, at 2147 (noting that Professors Issacharoff and Nagareda's proposal might have a different result).

172. As argued above, courts that have barred collateral attack have relied-explicitly or implicitly_ - on either a virtual representation theory or a waiver theory. See supra Part III.A.

173. See Issacharoff \& Nagareda, supra note 6, at 1716.

174. See FED. R. CIV. P. 23(a)(4), (e), (g); see also Kahan \& Silberman, The Inadequate Search, supra note 5, at 781-82 ("The judge in F-1, who approves a settlement and makes a finding of adequate representation (as well as substantive fairness), will be in a position - in fact, is requiredto find out whether class counsel up to this point adequately represented the class members."). Indeed, courts have recognized this obligation even while upholding the right to collateral attack. See, e.g., Johnson v. Shreveport Garment Co., 422 F. Supp. 526, 533 (W.D. La. 1976) (noting that a court, "as trustee for the absent parties, must evaluate the class representative's conduct of the entire litigation," but recognizing that a court is powerless to bind absent class members to a judgment unless they are adequately represented at every stage of the proceedings) (citing Gonzales v. Cassidy, 474 F.2d 67, 72 (5th Cir. 1973)).

175. See, e.g., Mullenix, supra note 20, at 1717 (arguing that the court's "independent interest in settling cases on its docket" means that "most courts are unlikely to engage in an independent rigorous examination of ... the adequacy of the representation in accomplishing [a] settlement"); Richard A. Nagareda, Closure in Damage Class Settlements: The Godfather Guide to Opt-Out Rights, 2003 U. CHI. LEGAL F. 141, 164 (2003) ("Even the most conscientious of courts, moreover, must undertake class settlement review against the sirens' call to sign off on the deal as a means of docket clearance."); see also Woolley, supra note 3, at 412 n.120 (collecting academic literature on point). 
objector (and those similarly situated) than would even a hands-on court because a class court has dueling obligations as an impartial arbiter and a "fiduciary" of the class.

Peter Schuck vividly describes how Judge Weinstein acted as anything but a fiduciary of the class during the settlement negotiations in Agent Orange: "The real obstacle to a \$200 million settlement, [Special Master David] Shapiro soon realized, was not the chemical companies but Judge Weinstein.... All things considered, [Judge Weinstein] insisted, \$180 million plus interest was the fair amount." ${ }^{, 176}$ After meeting with Judge Weinstein, the special masters met with defense counsel and told them that class counsel "was not about to go below \$200 million."177 When defense counsel indicated that they might increase their offer, "Shapiro surprised them by urging them to "stay where you are. Let the judge get them off the \$200 million." "178 The case settled for $\$ 180$ million plus interest. ${ }^{179}$ But, as Professor Schuck notes, there is evidence that defendants were prepared to settle the case for much more than Judge Weinstein engineered. ${ }^{180}$

For all these reasons, the class judge - even with the aid of counsel-is not an appropriate substitute for an adequate objector. In short, to the extent issue preclusion is available to bar an absent class member on the basis of adequacy, it must be applied in accordance with the strict limits on representation set forth in Taylor $v$. Sturgell. ${ }^{181}$

\footnotetext{
176. SCHUCK, supra note 79, at 159. David Shapiro recalls:

As a negotiator, I did not regard any particular figure as objectively "fair" or "right." Instead I was guided by the principle that the parties themselves are the best judges of what is fair, and I asked myself, "What is the most I can get defendants to agree to without squeezing them for every last cent?" At that point in the game, that figure was $\$ 200$ million. After trial began, it might be higher. But the judge's perspective was different, more principled and I respect him for it. When I later explained to Len Rivkin why the judge stuck at $\$ 180$ million when he could have gotten more, Rivkin said, "The man's too much of an idealist."

177. Id. at 160 .

178. Id.

179. Id. at 165 .

180. Professor Schuck writes:

Most [defendants] were delighted with the outcome; according to Rivkin, Dow was pleased because "the amount they had to pay in settlement was so small." (One lawyer later indicated that his client, having studied what a jury might do to it, would have been willing to settle for twice the amount.) One disinterested observer who was very knowledgeable about the case had believed that the case could settle for $\$ 400$ million Newsweek, reporting on the settlement, wrote that defendants' lawyers "privately chortled that they had walked away after paying only ten cents on the dollar."

Id. at 166 .
}

Id.

181. 128 S. Ct. 2161, 2171-78 (2008). 


\section{Jurisdiction and Adequate Representation}

The argument that a class member's failure to contest the adequacy of representation in the class court constitutes a waiver of adequacy objections presupposes that the class court has power to compel an absent class member to appear for purposes of litigating her adequacy objections. That assumption is open to serious question.

In thinking about personal jurisdiction in ordinary litigation, it is critical to distinguish between two separate but interrelated issues: (1) whether a person can be subjected to the personal jurisdiction of a court, i.e., amenability to personal jurisdiction; ${ }^{182}$ and (2) whether the court has provided adequate notice that an individual has been subjected to the jurisdiction of the court and must appear to protect his interests. Although "personal jurisdiction" is often used to refer solely to the amenability requirement, there should be no doubt that personal jurisdiction in ordinary litigation also requires notice that the person who has been sued must appear to protect his interests. ${ }^{183}$ In Griffin v. Griffin, for example, the United States Supreme Court had no difficulty concluding that a judgment "without actual notice to or appearance by petitioner, and without any form of service of process calculated to give him notice of the proceedings" meant that there was a "want of that jurisdiction over the person... prerequisite to the rendition of a judgment in personam against him." 184

The interrelationship between notice and amenability is evident in the fact that service of process on an individual within the forum state may serve both to establish amenability to personal jurisdiction and to provide notice that an appearance is necessary. But the amenability requirement nonetheless has its source in concerns distinct from the

182. In The Availability of Collateral Attack, I referred to this requirement as the "jurisdictional nexus" requirement. Woolley, supra note 3, at 395.

183. See Eugene F. Scoles \& Peter Hay, Conflict of Laws, \$5.16 at 324 (4th ed. 2004) ("In the United States there are other preconditions to effective judicial action commonly termed 'jurisdictional.' One important requirement is that the defendant be given reasonable notice of the proceedings against him."); Harold L. Korn, The Development of Judicial Jurisdiction in the United States: Part I, 65 BROOK. L. REV. 935, 970 (1999) (noting that notice and an opportunity to be heard are part of "Anglo-American conceptions of judicial jurisdiction"); Developments in the Law-State Court Jurisdiction, 73 HARV. L. REV. 909, 987 (1960) ("Since failure to provide proper notice, like absence of jurisdiction over the parties, will subject a judgment to collateral attack, it has been said that adequate notice is a prerequisite to jurisdiction.").

184. 327 U.S. 220, 228 (1946). ("Because of the [lack of notice], and to the extent that petitioner was thus deprived of an opportunity to raise defenses otherwise open to him under the law of New York against the docketing of judgment for accrued alimony, there was a want of judicial due process, and hence want of that jurisdiction over the person of petitioner prerequisite to the rendition of a judgment in personam against him.”). 
notice requirement. The amenability requirement is designed to protect an individual's liberty interest in avoiding a forum that lacks an appropriate connection with or that would be seriously inconvenient for the litigant. The notice requirement, by contrast, is designed to put a person on notice that he must defend the underlying property or liberty interest at stake in the proceeding on pain of adverse consequences.

Hansberry v. Lee-the Court's seminal decision on personal jurisdiction in class suits - held that adequate representation in class litigation can substitute for service of process in ordinary litigation. ${ }^{185}$ The Hansberry Court cited Pennoyer $v$. Neff for the traditional rulenow defunct - that in personam jurisdiction in ordinary litigation requires service of process on the litigant within the forum. ${ }^{186}$ But while the amenability requirement may now be satisfied without service of process in the forum, adequacy remains at the core of the jurisdictional inquiry in class actions. ${ }^{187}$ As I explain below, the policies that underlie the notice and amenability requirements in ordinary litigation generally are implemented through the adequate representation requirement in class litigation.

\section{Adequate Representation as a Substitute for Service of Process}

Service of process provides notice that a person must appear in the litigation to protect his or her interests. But such notice is unnecessary in a class suit. ${ }^{188}$ The very idea that absent class members must appear in the litigation to defend their interests is inconsistent with the representative nature of class suits. ${ }^{189}$ As Shutts explained, "an absent

185. Hansberry v. Lee, 311 U.S. 32, 41 (1940) (stating that in some circumstances adequate representation "may bind members of the class ... who were not made parties" through service of process).

186. Id. at 40 ("It is a principle of general application in Anglo-American jurisprudence that one is not bound by a judgment in personam in a litigation in which he is not designated as a party or to which he has not been made a party by service of process.") (citing Pennoyer v. Neff, 95 U.S. 714 (1877)).

187. See infra Part III.C.1-5; see also Diane P. Wood, Adjudicatory Jurisdiction and Class Actions, 62 IND. L.J. 597, 621 (1987) (recognizing that under a representational model "the decision of the plaintiff representative to bring the action in a particular state is enough to support the jurisdiction of the forum to rule on the claims of the remainder of the class as well . . as long as the plaintiff adequately represents the class.").

188. I have argued elsewhere, see Woolley, supra note 18 , at 571 , that notice-as opposed to process - is nonetheless required to protect an absent class member's "opportunity to be heard and participate in the litigation." Phillips Petroleum Co. v. Shutts, 472 U.S. 787, 812 (1985) (emphasis added).

189. As the Fifth Circuit has explained:

The purpose of Rule 23 would be subverted by requiring a class member who learns of a pending suit involving a class of which he is a part to monitor that litigation to make 
class action plaintiff is not required to do anything. He may sit back and allow the litigation to run its course, content in knowing that there are safeguards for his protection." 190 Because adequate representation in class litigation substitutes for service of process in ordinary litigation, adequate representation is properly understood as a prerequisite to personal jurisdiction over absent class members.

The requirement in Shutts that absent class members receive "notice plus an opportunity to be heard and participate in the litigation"191 has sometimes led to confusion on this point. If Shutts requires notice and an opportunity to be heard - precisely what service of process provideswhy should adequate representation have jurisdictional significance? Put simply, notice and opportunity to be heard provide absent class members with an option to participate; ${ }^{192}$ service of process, by contrast, notifies a person of a command to participate or suffer the risk of adverse consequences. It is adequate representation-not the option to participate - that renders unnecessary service of process on absent class members.

Congress or a state legislature, of course, is free to conclude that efficient aggregation requires that mass litigation be only partly

certain that his interests are being protected; this is not his responsibility-it is the responsibility of the class representative to protect the interests of all class members.

Gonzales v. Cassidy, 474 F.2d 67, 76 (5th Cir. 1973). See also Lilly, supra note 3, at 1049 ("Once an absent member is compelled to channel her adequacy objections into the class court, she no longer retains the privilege of a represented plaintiff who may sit back and allow the litigation to run its course under the guidance of the class representative and the class counsel."); Woolley, supra note 3, at 397-99 (recognizing that the fundamental character of a class suit is its representative nature" and noting that requiring absent class members to assert an objection in the class proceedings would be "a major step away from the representative model"); infra notes 192-96 and accompanying text.

190. Shutts, 472 U.S. at 810 .

191. Id. at 812 .

192. As Federal Practice and Procedure has cogently explained:

Actual notice, the opportunity to opt out (when it is afforded), the opportunity to appear and participate, and the opportunity to object to settlement, are opportunities. They are not obligations. Representative class members, class counsel, the court, and a class adversary who wishes the security of preclusion are responsible for ensuring actually adequate representation.

WrIGHT ET AL., supra note 3, at 485. See also George M. Strickler, Jr., Protecting the Class: The Search for the Adequate Representative in Class Action Litigation, 34 DePAUl L. REV. 73, 157

(1985). Professor Strickler emphatically rejects

the suggestion that a class member who receives notice and passively acquiesces in the action in some way commits himself or herself to the representative team and accepts the binding effect of the litigation regardless of the representative's performance. Neither Rule 23 nor the due process clause allows such an anomalous result. A class member who has elected to remain in the class has not waived the right ... to seek to be relieved from a judgment or settlement of the class claim. 
representative and to amend the federal or state class rule accordingly to permit process-like notice. ${ }^{193}$ But nothing in the text of Federal Rule 23 authorizes class courts to require absent class members to raise adequacy objections in the class court, and the Advisory Committee notes make clear that the omission was not a drafting error. The drafters of Federal Rule 23 cited section 116 of the Restatement of Judgments, comment b of which provides in relevant part: "Where a person is not a party to a class action the judgment therein has conclusive effect against him only if his interests were adequately represented ... [A] person as to whom a class action is ineffective is not required to seek relief during the continuance of the action...."194 The understanding reflected in the text of Federal Rule 23, and expressly stated in section 116 of the First Restatement represented the consensus view until quite recently. ${ }^{195}$ Thus, it would be a mistake to construe Rule 23 (and its state-law equivalents) as granting courts power under Rule 23 (or its state-law equivalents) to issue process-like notices compelling absentees to raise adequacy objections in the class court. ${ }^{196}$ For this reason alone, the failure of an absent class member to raise adequacy objections in the class suit itself cannot constitute a waiver of the argument that he or she has been inadequately represented.

But even if a court were granted authority to issue process-like notice requiring absent class members to litigate their adequacy objections in the class court, personal jurisdiction requirements would limit that grant of authority in connection with absent class members who lack minimum contacts with the class forum. As I explain in the next three subparts, if a class member lacks minimum contacts with the forum, his failure to opt out does not permit the class court to insist that the absent class member assert any objections to the adequacy of representation in the class court.

193. Professor Rubenstein would be in favor of such a rule. He suggests that an absent class member who fails to appear or opt out of the litigation should be deemed to have waived a collateral attack on the class judgment, at least if the class member has the appropriate territorial connection with the class forum. Rubenstein, supra note 1, at 865-66.

194. Restatement of Judgments $\S 116 \mathrm{cmt}$. b (1942) (emphasis added). The Second Restatement is in accord. See supra note 9.

195. See supra notes 189-92 and accompanying text; see also supra notes 2-4 and accompanying text.

196. RESTATEMENT (SECOND) OF JUDGMENTS $\S 42 \mathrm{cmt}$. b (contrasting the use of notice in class actions with process in ordinary litigation); supra note 189. 


\section{Amenability to Personal Jurisdiction in the Absence of Consent}

Aggregate Litigation fundamentally misconceives the role of personal jurisdiction in multistate class litigation. Indeed, in the context of class actions, Professors Issacharoff and Nagareda are remarkably dismissive of limits on the authority of courts to exercise personal jurisdiction over persons lacking an appropriate connection with the forum state. They write:

The simple fact is that national markets transcend the territorial boundaries of particular states. As a result, national markets give rise to both legal claims and demands for closure that are national in scope. Where jurisdiction realistically cannot turn on some vestigial notion of territoriality, the basis for the rendering court's assertion of authority over absent class members must proceed on some other basis-in Shutts, implied consent to a process that combines rights in the nature of self-help (exit and voice rights) with a right to oversight by fiduciaries (loyalty rights) $\ldots . .19$

As I discuss below, there is little doubt that Congress may authorize federal courts to exercise nationwide personal jurisdiction over absent members of a class. ${ }^{198}$ But in suggesting that the existence of national markets that give rise to claims and demands for closure that are national in scope somehow relaxes the limits on state-court personal jurisdiction, Professors Issacharoff and Nagareda suggest that traditional understandings of personal jurisdiction in the context of class actions are simply outmoded. But, if anything, respect for the traditional conception of personal jurisdiction is especially important in sprawling multistate class suits, which may draw into their webs absent class members who lack an appropriate connection with the forum state. And Shutts-on which Professors Issacharoff and Nagareda heavily rely to support their jurisdictional argument-cannot properly be understood except in the context of the policies served by the amenability requirement.

In ordinary litigation, a person is amenable to the personal jurisdiction of a state if (1) she has minimum contacts with the state and

197. Issacharoff \& Nagareda, supra note 6, at 1702 (citing Shutts, 472 U.S. at 809). For an article briefly discussing the possibility that Congress has power to free state courts from ordinary limits on state personal jurisdiction in some contexts, see Robert C. Casad, Personal Jurisdiction in Federal Question Cases, 70 TEX. L. REV. 1589, 1615-21 (1992). I am skeptical that Congress has the power to free state courts from the limits on state court personal jurisdiction imposed by the Fourteenth Amendment Due Process Clause. See City of Boerne v. Flores, 521 U.S. 507, 519 (1997) ("Congress' power under $\S 5 \ldots$ extends only to 'enforc[ing]' the provisions of the Fourteenth Amendment.").

198. See infra Part III.C.5 
(2) the exercise of jurisdiction in that state would be reasonable. ${ }^{199}$ As I discuss below, the minimum contacts prong protects a person from being subjected to the personal jurisdiction of a forum state that does not have an appropriate connection with the person whose rights are being adjudicated. The reasonableness prong, on the other hand, protects a person from being haled into a forum that is unreasonably inconvenient.

It has been argued that personal jurisdiction should be understood to simply protect against inconvenience. ${ }^{200}$ But the Court's cases strongly suggest that protecting against inconvenience is not the primary function of personal jurisdiction. In World-Wide Volkswagen, for example, the Court stated that limits on personal jurisdiction are designed both to protect state sovereign authority and to protect individuals from being haled into an inconvenient forum. ${ }^{201}$ The Court later backed away from the assertion that personal jurisdiction independently protects state sovereign authority, concluding instead that limits on personal jurisdiction are intended to protect the liberty interests of individual persons. ${ }^{202}$ But the conclusion that limits on personal jurisdiction protect

199. See Burger King Corp. v. Rudzewicz, 471 U.S. 462, 477 (1985). I address only the limits on personal jurisdiction imposed by the Constitution. In so doing, I assume for purposes of this discussion that, in the absence of consent, amenability to personal jurisdiction in ordinary litigation requires minimum contacts. See Shaffer v. Heitner, 433 U.S. 186, 212 (1977) ("We therefore conclude that all assertions of state court territorial jurisdiction must be evaluated according to the standards set forth in International Shoe and its progeny."). Courts have recognized other constitutionally sufficient bases for personal jurisdiction, none of which appear relevant to the question at hand: the constitutional limits on personal jurisdiction in class suits for money damages.

200. See, e.g., Martin H. Redish, Due Process, Federalism, and Personal Jurisdiction: A Theoretical Evaluation, 75 Nw. U. L. REV. 1112, 1137 (1981) ("[T]he only concern of a principled due process jurisdictional analysis should be the avoidance of inconvenience to the defendant."); Ralph U. Whitten, Constitutional Limitations on State-Court Jurisdiction: A Historical-Interpretive Reexamination of the Full Faith and Credit and Due Process Clauses (Part Two), 14 CREIGHTON L. REV. 735, 846 (1981) (stating that a court should have "jurisdiction to adjudicate an action against any defendant, unless the defendant demonstrates that the relative burdens imposed by suit in the particular court are so great that the defendant is, as a practical matter, unable to defend there adequately."); see also Louise Weinberg, The Place of Trial and the Law Applied: Overhauling Constitutional Theory, 59 U. CoLO. L. REV. 67, 102 (1988) ("Given the availability of forum non conveniens, and independent review of choice of law for fundamental fairness, defendants simply do not need all of the constitutional protection from plaintiff's choice of forum that the Supreme Court keeps lavishing on them.").

201. World-Wide Volkswagen Corp. v. Woodson, 444 U.S. 286, 292 (1980).

202. See Ins. Corp. of Ireland, Ltd. v. Compagnie des Bauxites de Guinée, 456 U.S. 694, 702 \& n.10 (1982) ("The personal jurisdiction requirement recognizes and protects an individual liberty interest. It represents a restriction on judicial power not as a matter of sovereignty, but as a matter of individual liberty."). Shutts explained that the "purpose" of the jurisdictional test "is to protect a defendant from the travail of defending in a distant forum, unless the defendant's contacts with the forum make it just to force him to defend there." Phillips Petroleum Co. v. Shutts, 472 U.S. 797, 807 (1985). I do not read the reference to the "travail of defending in a distant forum" as suggesting that limits on personal jurisdiction are designed to protect solely against inconvenience. Rather, I read that phrase as referring to the burdens of litigating in any forum that is not the litigant's home 
mostly against inconvenience is at odds with the continued insistence of the Court that, before a forum state may exercise personal jurisdiction without consent, the person must have purposeful contacts of a nature and quality to justify the exercise of personal jurisdiction.

The purposeful-contacts requirement cannot be explained on the basis of convenience, as a simple example demonstrates. Suppose $A$ lives in New York, but has never established purposeful contacts with New Jersey. Litigation in New Jersey might nonetheless be more convenient for $A$-if, for example, $A$ lives much closer to a courthouse in New Jersey than New York. Yet, in the absence of purposeful contacts, New Jersey will not be able to exercise personal jurisdiction over $A$ without $A$ 's consent. $A$ might choose not to consent if New York would be a more advantageous forum-if, for example, New York's jury practice would be more favorable to $A$ 's case than New Jersey's or if New York's choice-of-law rules would lead to a more favorable result.

The point is that states have enormous latitude in structuring the background rules that govern adjudication of disputes in their courts. And those rules may have a substantial effect on the outcome of the litigation. $^{203}$ For that reason, fundamental fairness properly can be said to require that only states with an appropriate connection to a person have power to force that person or his representatives to appear without consent. $^{204}$ The purposeful-contacts requirement, in other words,

base. As I discuss in the text below, these burdens include the application of the forum's choice-oflaw rules, jury rules, etc. See infra note 203 and accompanying text.

203. See Harold G. Maier \& Thomas R. McCoy, A Unifying Theory for Judicial Jurisdiction and Choice of Law, 39 AM. J. COMP. L. 249, 255 (1991) ("Choice of judicial jurisdiction is choice of law because choosing a jurisdiction chooses the legal regime that will select, interpret and apply the policies that will determine the result in the particular case."). Professors Maier and McCoy formulate the point even more broadly:

The legal result in a case is influenced by many attributes of the forum in addition to the rules of law that it chooses to apply. These attributes include the local predilections, vagaries, biases and informal understandings of the forum's juries and judges, e.g., the local propensities of juries to act in given ways independent of the legal rules under which they are charged, and the judicial biases conditioned by experience and custom in the community that the judge serves.

Id. at 253-54 (footnotes omitted); see also Edward H. Cooper, Rewriting Shutts for Fun, Not to Profit, 74 UMKC L. REV. 569, 575 (2006) (recognizing that the forum-sovereign "will supply its own judge, draw the jury if the case progresses to trial in that mode, apply its own procedure, make the choice of governing 'substantive' law, and determine the content of the chosen law," and noting that "one sovereign may behave quite differently from others").

204. My colleague, Russell Weintraub, has proposed a radical simplification of the jurisdictional inquiry. He argues that due process should be understood to require "only that the forum have some rational basis for wishing to decide the case, either because the plaintiff resides there or because the defendant acted or caused consequences there, or both." RUSSELL J. WEINTRAUB, COMMENTARY ON THE CONFLICT OF LAWS 196 (2006) (discussing suits by United States plaintiffs against United States defendants). Professor Weintraub would deal with any "unfairness" by "transfer to a more 
protects a person's liberty interest in being free from the exercise of sovereign authority by states that lack an appropriate connection with the person. $^{20}$

The second prong of the amenability analysis protects against deprivations of liberty that would result from requiring a person to litigate in a seriously inconvenient forum. As set out in Burger King, the court must weigh a number of factors, including inconvenience to the defendant, typically the party challenging the personal jurisdiction of the court. ${ }^{206}$ While inconvenience to the defendant is only one of the factors considered by the Court, it is of necessity the focal point of the inquiry. In ordinary litigation, after all, it is only the defendant who is required to appear in the forum state and thus be deprived of liberty in a manner that invokes the protections of the Due Process Clause. Put another way, the

appropriate forum." Id. His proposal recognizes that a forum's choice-of-law rules may be a serious source of unfairness:

If the forum's sole nexus is the plaintiff's residence, it would be unfair to the defendant to allow suit there if this would result in choosing law more unfavorable to the defendant than would be chosen in all states that have contacts with both the parties and the transaction.

Id. I share Professor Weintraub's frustration with the complexity of current constitutional doctrine and the irrationality of some court decisions, but I do not think his proposal adequately takes into account the substantial effect the choice of forum may have on the outcome of the litigation.

205. Cf. LEA BRILMAYER, CONFLICT OF LAwS $\S 6.1$ at 270 (2d ed. 1995) ("The connection between sovereignty and personal jurisdiction doctrine is that states are simply not entitled to assert their authority over individuals who lack an appropriate connection."); id. at 271 ("In personal jurisdiction, it is the individual's right to be left alone by a state that has no legitimate authority over him or her that the due process clause protects."). While I generally agree with Professor Brilmayer that an exercise of jurisdictional authority requires "an appropriate connection" between an individual and a forum state, I believe that "fundamental fairness" occasionally permit exceptions. I am not troubled, for example, by the fact that Shutts permits states to require that absent class members who wish to pursue litigation individually opt-out, even if class members lack contacts with the forum state. Fundamental fairness requires an "appropriate connection" with the forum because "states have enormous latitude in structuring the background rules that govern adjudication of disputes in their courts," and "those rules may have a substantial effect on the outcome of the litigation." See supra note 203 and accompanying text. As I discuss below, Shutts adequately takes these considerations into account through the adequate representation requirement.

206. Burger King Corp. v. Rudzewicz, 471 U.S. 462, 477 (1985) (identifying factors to be weighed as "'the burden on the defendant,' 'the forum State's interest in adjudicating the dispute,' 'the plaintiff's interest in obtaining convenient and effective relief,' 'the interstate judicial system's interest in obtaining the most efficient resolution of controversies,' and the 'shared interest of the several States in furthering fundamental substantive social policies"') (quoting World-Wide Volkswagen, 444 U.S. at 292); see also Asahi Metal Indus. Co. v. Sup. Court, 480 U.S. 102, 115 (1987) (noting that in cases with connections to foreign countries, the fifth factor should be understood to call for consideration of "the procedural and substantive policies of other nations whose interests are affected by the assertion of jurisdiction by the California court"); id. (noting that the interests of other nations "as well as the Federal Government's interest in its foreign relations policies, will be best served by a careful inquiry into the reasonableness of the assertion of jurisdiction in the particular case, and an unwillingness to find the serious burdens on an alien defendant outweighed by minimal interests on the part of the plaintiff or the forum State"). 
key question is whether the inconvenience to the defendant is of sufficient magnitude - in light of the other interests at stake - to violate due process.

For good reason, there is no reference in Shutts to the reasonableness prong. As the Court noted, what distinguishes class litigation from ordinary litigation is that an absent class member may sit back and "allow the litigation to run its course, content in knowing that there are safeguards provided for his protection."207 In other words, the court and class counsel are required to protect the interests of an absent class member. Because a class member need not appear in the forum to protect his or her interests, there is no reason to think that inconvenience resulting from litigation in a particular forum could be sufficiently serious to give rise to a constitutional injury. Thus, the Court's failure to even discuss the reasonableness prong in Shutts provides further evidence that class action rules do not require an absent class member to raise an adequacy objection in the class court on pain of waiver.

\section{Consent and the Role of Adequate Representation}

Proponents of limitations on collateral attack have ridiculed the notion that adequate representation has any role to play in whether a court has personal jurisdiction over an absent class member, ${ }^{208}$ often arguing instead that the failure to opt out-without more-constitutes consent to the personal jurisdiction of a class court. ${ }^{209}$ There is no question that consent is an adequate basis for the exercise of personal jurisdiction. The much harder question is whether a simple failure to opt out - assuming adequate notice-provides a sufficient basis for concluding that an absent class member has consented to personal jurisdiction.

The jurisdictional significance that Shutts attaches to a failure to opt out of a class suit is unique in the annals of personal jurisdiction. There is no other context in which a forum that lacks an appropriate territorial

\section{Shutts, 472 U.S. at 810}

208. Nagareda, Administering Adequacy, supra note 6, at 311 (criticizing Professor Monaghan as subscribing to the view that personal jurisdiction in Shutts is of a "provisional, twilight-zone" nature). (citing Henry Paul Monaghan, Antisuit Injunctions and Preclusion Against Absent Nonresident Class Members, 98 ColuM. L. ReV. 1148, 1173, 1179, 1183, 1186, 1197 (1998)).

209. See, e.g., Kahan \& Silberman, Matsushita, supra note 5, at 263-64 (arguing that notice and an opportunity to opt out are sufficient for the exercise of personal jurisdiction over absent class members); see also Monaghan, supra note 208, at 1173 ("[C]ourts and commentators alike have focused on Shutts's requirement of a right to opt out of damage claims as a sufficient condition for the exercise of in personam jurisdiction."). Professors Issacharoff and Nagareda have a more nuanced position. See supra note 197 and accompanying text. 
connection to a person can require a person to do anything. ${ }^{210}$ It is true, of course, that a party who appears in litigation may waive his or her jurisdictional objection by failing to comply with the procedural rules of the forum. ${ }^{211}$ But in such a case, the party has in fact done something. By entering an appearance, the party who claims that the court lacks personal jurisdiction has at a minimum consented to the personal jurisdiction of the court for the limited purpose of having his or her jurisdictional objections adjudicated in accordance with the procedural rules of the forum. ${ }^{212}$

A class court's power to treat a failure to opt out as jurisdictionally significant cannot be explained by asserting that territorial connections between the litigant and the forum are less important in the class context than in others. Absent class members subjected to the personal jurisdiction of a court are no less bound by the forum's rules than other litigants, ${ }^{213}$ and it is the primary role of personal jurisdiction to protect persons without an appropriate connection to the forum from being subjected to the rules of the forum. What makes class litigation different is that an absent class member need not appear in the forum to protect his or her interests. It is worth quoting Shutts at length on this point:

Petitioner claims that failure to execute and return the "request for exclusion" provided with the class notice cannot constitute consent of the out-of-state plaintiffs ....

210. See Lilly, supra note 3, at 1034. Professor Lilly explains: "In ordinary litigation, there is no instance in which a defendant is brought within a court's personal jurisdiction by the simple failure to respond to a summons or other document from the court. Such a rule would very likely be unconstitutional." Id.

211. FeD. R. CIV. P. 12(g), (h); see also Ins. Corp. of Ireland v. Compagnie des Bauxites de Guinée, 456 U.S. 694, 705 (1982) (recognizing that "the failure to enter a timely objection to personal jurisdiction constitutes, under Rule 12(h)(1), a waiver of the objection").

212. Professor Lilly provides another example:

Rule 4 of the Federal Rules of Civil Procedure, for example, allows waiver of the formal service of process, but it still requires the recipient to make affirmative contact with the court to extend the court's jurisdiction over the non-resident. The Advisory Committee in fact explicitly rejected the idea that a court could extend personal jurisdiction over a non-resident defendant merely through his failure to respond to mailed service. While it is true that personal jurisdiction can, for example, be acquired through a consent transmitted by mail, the defendant must affirmatively register her submission to this territorial jurisdiction.

Lilly, supra note 3 , at $1034-35$.

213. It is true that absent class members may not be bound by certain rules inconsistent with their status as absentees, but as with any litigant, they are subject to the forum's conflict-of-law rules, jury-trial rules, summary-judgment rules, etc. 
We think the petitioner's premise is in error. The burdens placed by a state upon an absent class action plaintiff are not of the same order or magnitude as those it places upon an absent defendant. ...

... The court and named plaintiffs protect his interests....

Besides this continuing solicitude for their rights, absent plaintiff class members are not subject to other burdens imposed upon defendants. They need not hire counsel or appear. ...

Unlike a defendant in a normal civil suit, an absent class action plaintiff is not required to do anything. He may sit back and allow the litigation to run its course, content in knowing that there are safeguards provided for his protection.

In short, the Court in Shutts focused heavily on the fact that an individual will not have to act in the forum to protect his interests. If an individual were required to appear in the forum to protect his interestsas he might well have to do if he were denied the right to collaterally attack a judgment for inadequate representation - he would be stripped of the very protection on which the Court relied to conclude that a failure to opt out could be deemed jurisdictionally significant in the class context.

Tobias Wolff has persuasively argued that a failure to opt out provides little evidence of actual consent. ${ }^{215}$ For that reason, he believes that Shutts is best understood as a case of constructive consent:

[C]lass members should be bound by the proceeding as if they had "consented" (or consciously passed up the opportunity to object) because the Court believes that, given the type of claim at issue and the mechanisms in place for its resolution, some set of core valuesdeterrence, fairness, efficiency, even-handed administration of similar claims - will be well served by that legal fiction. ${ }^{216}$

214. Phillips Petroleum Co. v. Shutts, 472 U.S. 797, 806-10 (1985).

215. See Tobias Barrington Wolff, Federal Jurisdiction and Due Process in the Era of the Nationwide Class Action, 156 U. PA. L. REV. 2035, 2088-90 (2008) (rejecting as empirically unfounded the Shutts Court's assumption that "it is generally appropriate to treat the notice and optout procedure as one that elicits a meaningful expression of simple consent from class members ('unwilling to execute an opt out form') or, at least, as one that generally causes the class member to become engaged with the proceedings in a sufficiently active manner that it is appropriate to treat a failure to respond as a waiver of objections and, hence, as procedural consent ("presumed to consent to being a member of the class by his failure to do so')") (footnotes omitted).

216. Id. at 2092. 
There is much to be said for Professor Wolff's view-a view that supports the conclusion that a failure to opt out is not alone sufficient to establish personal jurisdiction.

But I would articulate differently the justification for authorizing jurisdiction over individuals who cannot realistically be said to consent to personal jurisdiction. Put simply, the adequate-representation requirement - properly understood — safeguards the fundamental policies effectuated through the amenability requirement of personal jurisdiction. Because a class member is represented in the litigation and need not appear for any reason, the protection against inconvenience offered through the reasonableness prong is superfluous. Moreover, adequate representation-properly understood-provides an absent class member with no less protection against the sovereign authority of the forum than does the appropriate-connection requirement. Unless otherwise required by a forum with an appropriate connection to the class member, an adequate representative must pursue the claims of an absentee in the forum that would best serve the interests of the absent class member, all things considered. ${ }^{217}$ An absent class member, for example, might benefit more from being part of the class suit than filing an individual suit in a different forum with more advantageous choice-of-law rules. ${ }^{218}$ But assuming that the class member is adequately represented, he will not be prejudiced by having his claims resolved by a sovereign that lacks an appropriate connection with the class member. ${ }^{219}$ For all these reasons, adequate representation, without more, adequately serves the policies implemented by the amenability requirement, at least for absent class members who would not otherwise involve themselves in the litigation.

To the extent a class member is motivated and sophisticated enough to determine for herself the desirability of the forum, however, she is entitled to an opportunity to grant or withhold consent to personal jurisdiction; class members should not be required to accept the compromises inherent in adequate representation if they wish to participate in the litigation. ${ }^{220}$ But given the administrative difficulties

217. See Woolley, Choice of Law, supra note 16, at 832-35.

218. Id. at 827 ("When obtaining an otherwise beneficial choice-of-law decision would risk making the class device unavailable, careful consideration of the risks involved for the affected portion of the class might properly lead class counsel to forego certain choice-of-law arguments.").

219. A court with an appropriate connection to an absent class member may have power under the Constitution to require litigation of his or her claims in the forum through a representative even if another forum would be more advantageous for the absent class member. See id. at 832-35.

220. See Woolley, Shutts and the Adequate Representation Requirement, supra note 16, at 772 $\mathrm{n} .53$ ("It is in part because the practicalities of class litigation require class counsel to represent 
inherent in determining whether a particular class member should be deemed motivated and sophisticated, it seems clear that identical procedures must be used to resolve jurisdictional questions for all class members. So while an affirmative manifestation of consent to personal jurisdiction might be the ideal way to determine whether a motivated and sophisticated class member consents to personal jurisdiction, nothing so burdensome is required. If notice is received and sufficiently clear to meet the requirements of procedural due process, ${ }^{221}$ a failure to opt out is sufficient to manifest consent, ${ }^{222}$ provided the class member need not appear in the forum to protect his or her interest in adequate representation.

\section{Limited Jurisdiction in Class Litigation}

Relying on the close link between adequate representation and personal jurisdiction suggested in Shutts, Henry Monaghan argued in a path-breaking article that the failure to opt out of a class suit represents a "limited and conditional" consent to the personal jurisdiction of the class

parties whose interests are not perfectly aligned that class members should be offered either an opportunity to be heard and participate in the litigation or an opportunity to opt-out.").

221. Given the protections offered in class litigation, the Court concluded that service of process is not required, provided that notice is "receive[d]." Phillips Petroleum Co. v. Shutts, 472 U.S. 797, 812 (1985) (emphasis added); cf. Silber v. Mabon, 18 F.3d 1449, 1453-54 (9th Cir. 1994) (arguing that Shutts does not require actual receipt of notice); Cooper, supra note 203, at 576 ("The common understanding is that actual notice is not required - the absent class member can be bound by a judgment, or settlement, without having known of the action."); Arthur R. Miller \& David Crump, Jurisdiction and Choice of Law in Multistate Class Actions After Phillips Petroleum Co. v. Shutts, 96 YALE L.J. 1, 20 (1986) ("[T]he most appropriate reading of Shutts may be that class members constitutionally may be included if first-class mail is directed to them and is not returned as undeliverable."). I do not attempt to determine in this Article whether notice must be actually received.

222. Shutts, 472 U.S. at 813 ("[T] $]$ he Constitution does not require more to protect what must be the somewhat rare species of class member who is unwilling to execute an 'opt out' form, but whose claim is nonetheless so important that he cannot be presumed to consent to being a member of the class by his failure to do so."). Because no explicit manifestation of consent is required, the opt-out right in this context can best be described - as Lea Brilmayer and Jack Goldsmith have suggestedas a form of implied consent in fact (in contrast to the implied consent in law criticized by the Court in International Shoe). See L. Brilmayer \& J. GoldSMith, CONFLiCT OF LAWS (5, at 479. 
court premised on adequate representation of the class member. ${ }^{223}$ I endorsed this view in my first article on collateral attack. ${ }^{224}$

The conditional consent paradigm has the virtue of emphasizing the close link between adequate representation and personal jurisdiction, a link that largely had been ignored before Professor Monaghan published his path-breaking article. ${ }^{225}$ But in the absence of minimum contacts, personal jurisdiction in class litigation is even more precisely described as a form of limited jurisdiction. Put simply, a class court has power to enter a judgment against an absent class member on the basis of adequate representation, but no power to compel an absent class member to appear in the forum to contest adequate representation or anything else. After all, the Court's conclusion in Shutts - that express consent was not required-rested on the premise that an absent class member is not required to do anything. ${ }^{226}$

The concept of limited jurisdiction is an old one, regularly used, for example, when courts routinely asserted quasi-in-rem jurisdiction by seizing property of the defendant within the jurisdiction. ${ }^{227}$ A seizure of property did not give a court in personam jurisdiction over the defendant, but allowed a court to adjudicate the dispute and satisfy any resulting judgment from the proceeds of the seized property. ${ }^{228}$ Thus, the jurisdiction of a court premised on the seizure of property had limited consequences for a defendant who did not appear in the litigation. ${ }^{229}$

223. See Monaghan, supra note 208, at 1154 ("[W]hether Shutts is read as a case of implied consent or fundamental fairness, the scope of in personam jurisdiction it countenances over nonresident class members lacking minimum contact with the forum is both limited and conditional."). Professor Monaghan believes the "fundamental fairness" approach is the sounder way of understanding Shutts. See id. at 1170 (arguing that Shutts is best understood as involving "jurisdictional forfeiture" and suggesting that "[i]n stretching to discover 'consent' .... Shutts drew upon the Court's longstanding jurisprudential practice: results are initially explained in terms of an 'implied' consent, and the fictional nature of that explanation is subsequently admitted").

224. See Woolley, supra note 3 , at 395.

225. Monaghan, supra note 208, at 1166

226. Shutts, 472 U.S. at 811.

227. 4A Charles Alan Wright \& Arthur R. Miller, Federal Practice and Procedure $\S 1070$ (2002).

228. Cooper v. Reynolds, 77 U.S. 308, 318 (1870) ("[I]f there is no appearance of the defendant, and no service of process on him, the case becomes, in its essential nature, a proceeding in rem, the only effect of which is to subject the property attached to the payment of the demand which the court may find to be due to the plaintiff."); RESTATEMENT (SECOND) OF JUDGMENTS § 32(3) cmt. b (1982) (noting that a valid judgment based on attachment jurisdiction is "conclusive" only "as to the application of the defendant's interest in the thing to the plaintiff's claim," and recognizing that "a personal judgment upon that claim cannot be given, nor can any other personal liability be imposed, unless the court has acquired jurisdiction over the defendant's person").

229. There is a split of authority on whether a defendant who appears in the litigation for the purpose of defending his or her property should be deemed to consent to the in personam jurisdiction of the court. See 4B WRIGHT \& MiLlER, supra note 227, § 1123 (collecting authority and 
So too does the reasoning in Shutts suggest that a failure to opt out of class litigation should have limited jurisdictional consequences. ${ }^{230}$ The claim that collateral attacks by absent class members who lack minimum contacts with the forum must nonetheless be heard in that forum is an attempt to evade the limited nature of the jurisdiction conferred by Shutts. For the same reason, the forum court lacks personal jurisdiction to enter an antisuit injunction against an absent class member simply because the class member failed to opt out of the litigation. Because a valid antisuit injunction subjects a person who violates the injunction to penalties for contempt of court, ${ }^{231}$ the limited jurisdiction authorized by Shutts cannot reasonably be read to give courts power to enter an antisuit injunction against an absent class member. ${ }^{232}$ The minimum-contact and reasonableness prongs must be satisfied, or the class member must have given express consent to personal jurisdiction, before an antisuit injunction may be entered against an absent class member consistently with the amenability requirement. ${ }^{233}$

summarizing the debate). Because absent class members do not appear in the litigation, this split of authority has no bearing on my argument.

230. In this vein, Professor Cooper notes that Shutts holds "that 'a forum State may exercise jurisdiction over the claim of an absent class action plaintiff, even though that plaintiff may not possess the minimum contacts with the forum which would support personal jurisdiction over a defendant." Cooper, supra note 203, at 570 (quoting Shutts, 472 U.S. 808). He then argues: "These words seem to distinguish 'personal jurisdiction' over a defendant from a nearly in rem jurisdiction over a class member's claim. That is a rather neat way of expressing the distinction between imposing a liability or extinguishing a claim and imposing significant burdens of litigating on pain of default." Id. Professor Cooper nonetheless contends that "the distinction is valid" only "up to a point," concluding that "a class member who does not wish to trust the class representation must do something to avoid preclusion, either by opting out or by participating in the action." Id.

231. See Rhonda Wasserman, The Curious Complications with Back-End Opt-Out Rights, 49 WM. \& MARY L. REV. 373, 413 (2008) (noting that if absent class members "violate an injunction that bars them from pressing their claims in state court or from presenting certain evidence in support of their claims, they can be held in criminal or civil contempt").

232. See id. (recognizing that holding an absent class member in contempt for violating an antisuit injunction is inconsistent with the express rationale of Shutts). Professor Wasserman has noted that Shutts

distinguished between the burdens borne by defendants and absent plaintiff class members: "[A]bsent plaintiff class members... are almost never subject to counterclaims or cross-claims, or liability for fees or costs. Absent plaintiff class members are not subject to coercive or punitive remedies. Nor will an adverse judgment typically bind an absent plaintiff for any damages . . .."

Id. at 412 (quoting Shutts, 472 U.S. at 810)

233. Lonny Sheinkopf Hoffman, Syngenta, Stephenson, and the Federal Judicial Injunctive Power, 37 AKRON L. REV. 605, 644 (2004) ("[A]n injunction by a federal district judge against a nonresident class member's collateral attack in a distant forum should not succeed unless the absent class member otherwise possesses sufficient minimum contacts with the forum state."); Monaghan, supra note 208, at 1179-87 (rejecting the view that a class court has personal jurisdiction to enter an antisuit injunction against absent class members lacking minimum contacts with the forum). As I discuss in the next subpart, the Constitution does not bar federal courts from using a national- 


\section{Amenability to Personal Jurisdiction in the Federal Courts}

My discussion so far has focused primarily on the constitutional constraints the amenability requirement imposes on the ability of state courts to limit collateral attack. The constitutional landscape is different with respect to federal courts.

There is substantial support for the view that federal courts may use a national-contacts standard consistently with the Due Process Clause of the Fifth Amendment. ${ }^{234}$ It is less clear, however, whether the Constitution requires a federal court using a national-contacts standard to weigh the reasonableness factors set forth in Burger King (or some substantial equivalent) before concluding that it may exercise personal jurisdiction over a person in ordinary litigation. ${ }^{235}$ There is much to be said for imposing a reasonableness requirement to limit the power of federal courts to exercise personal jurisdiction. States can be divested of personal jurisdiction when the forum is unreasonably inconvenient, and inconvenience would seem to be a much bigger problem in the context of nationwide personal jurisdiction. For that reason, a single-minded focus on whether a person has an appropriate connection with the nation seems perverse. ${ }^{236}$

If protection against unreasonable inconvenience is an integral part of a nationwide personal-jurisdiction analysis, the Constitution imposes jurisdictional limits on the ability of both state and federal courts to require absent class members to raise their jurisdictional objections in the

contacts standard. I do not address in this Article the argument that federal courts currently have statutory authority in limited circumstances to enforce an antisuit injunction against absent class members. See Wolff, supra note 215, at 2114 (noting that courts have held that enforcement of an injunction against nonparties is "clearly available when nonparties aid in subverting an order or violating its terms.").

234. See SCOLES ET AL., supra note 148, at 424-28 (collecting case law and commentary); Casad, supra note 197, at 1600 (noting that the view that the Fifth Amendment requires federal courts to use a state contacts standard "is not widely followed"). The use of a national-contacts standard by federal courts is consistent with my analysis of the fundamental policies underlying the minimum-contacts requirement. See supra Part III.C.2.

235. Burger King Corp. v. Rudzewicz, 471 U.S. 462, 477 (1985); see Casad, supra note 197, at 1601-06; Leslie M. Kelleher, Amenability to Jurisdiction as a "Substantive Right": The Invalidity of Rule 4(k) Under the Rules Enabling Act, 75 IND. L.J. 1191, 1217 (2000) ("Most courts have rejected the notion that even when sufficient affiliating contacts with the nation exist, the Fifth Amendment affords the defendant some additional protection from an inconvenient venue within the United States.").

236. If the constitutional basis for nationwide personal jurisdiction is properly premised on service of process within the nation rather than a contacts analysis, a reasonableness analysis may be unnecessary for that reason. Cf. Burnham v. Sup. Court, 495 U.S. 604, 610 (1990) (plurality opinion) ("Among the most firmly established principles of personal jurisdiction in American tradition is that the courts of a State have jurisdiction over nonresidents who are physically present in the State."). 
forum state. If, on the other hand, the Fifth Amendment does not protect against the exercise of personal jurisdiction in an "unreasonably inconvenient" forum, the Constitution likely imposes no jurisdictional constraints on the ability of a federal court to require absent class members who have minimum contacts with the United States to raise their adequacy objections in the class court. Assuming that an absent class member has received adequate notice and a fair opportunity to litigate the adequacy issue, I would argue that collateral attacks on federal class judgments are available only because federal courts currently have no authority to require absent class members to object to inadequate representation in the class proceedings. ${ }^{237}$ But should Congress authorize process-like notice to require absent class members to raise adequacy objections in the class proceeding, ${ }^{238}$ there likely would be no basis for a minimum-contacts objection to the exercise of personal jurisdiction by a federal court.

\section{CONCLUSION}

In this paper, I have set forth an understanding of adequate representation and collateral attack that is responsive to the values embedded in the adequate-representation standard, the demands of preclusion law, and the law of personal jurisdiction, as well as the need for reasonable finality of judgments. By contrast, Aggregate Litigation essentially rewrites the law of preclusion and of personal jurisdiction to ensure finality. Indeed, in defending their work, Professors Issacharoff and Nagareda have said that we need a new "litigation vocabulary"239 with respect to preclusion and have dismissed the importance of personal

237. See supra Part III.C.1.

238. I do not consider here whether a simple amendment to Rule 23 authorizing federal courts to issue process-like notice requiring absent class members to object in the class proceeding to inadequate representation would be consistent with the requirements of the Rules Enabling Act, 28 U.S.C. § 2072. Stephen Burbank has stated that, "It is a close question whether Federal Rules expanding the territorial jurisdiction of the federal courts are valid under the Act, interpreted in the light of the pre-1934 history." Stephen B. Burbank, The Rules Enabling Act of 1934, 130 U. PA. L. REV. 1015, 1172 n.673 (1982). The Supreme Court nonetheless held in an early case that the modest expansion of personal jurisdiction worked by then Rule 4(f) met the requirements of the Rules Enabling Act. See Miss. Publ'g Corp. v. Murphree, 326 U.S. 438, 445 (1946). Since then, the Court (as rule-maker) has approved Federal Rule of Civil Procedure 4(k)(2), a far more ambitious expansion of personal jurisdiction. See Kelleher, supra note 235, at 1219-22 (noting that Congress and the Court were aware of concerns that Rule 4(k)(2) might be inconsistent with the requirements of the Rules Enabling Act).

239. Issacharoff \& Nagareda, supra note 6, at 1654 ("Our claim is that the binding effect of a class settlement cannot be resolved simply within our inherited litigation vocabulary."). 
jurisdiction in multistate class actions. ${ }^{240}$ But while there is room even within the current vocabulary to limit collateral attack if doing so would be wise, our "litigation vocabulary" is rooted in basic understandings of Due Process. If we are to revise our basic understanding of what Due Process requires in the context of preclusion and personal jurisdiction, there should be a showing of necessity.

As I- and others - have noted, there is no evidence that collateral attacks pose a significant problem. ${ }^{241}$ But even if the empirical evidence were to support the view that the availability of collateral attack creates substantial problems, there is no reason to think that the problems could not be addressed without radically revising our understanding of due process. If a problem exists or even potentially exists, it may well be rooted in uncertainty about what adequate representation requires and what the appropriate standard of review on collateral attack should beboth matters that can be resolved by the United States Supreme Court. Congress can also respond, if necessary, without upending basic principles of preclusion law or fundamental limits on the personal jurisdiction of state courts. Indeed, Congress has power to virtually eliminate collateral attacks on federal class judgments by authorizing federal courts to issue process-like notice requiring absent class members to raise adequacy objections in the class court. ${ }^{242}$ And to the extent the problem with collateral attack is that "anomalous state courts" provide fertile fora for inappropriate collateral attacks on class judgments, ${ }^{243}$

240. Id.

241. Dana, supra note 3, at 322-23 ("Available evidence, although hardly definitive, strongly suggests that a rule allowing subsequent challenges to class action settlements will have at most a very modest effect on the incidence or timing of settlement in class actions."); Rubenstein, supra note 1, at 833 (noting that "there are but a small number of reported cases challenging class action settlements, particularly small when juxtaposed with the thousands of such actions filed annually," but acknowledging the possibility that collateral attacks may increase in number and significance); Wolff, supra note 215, at 2122 (noting that "it is still early," but recognizing that "there does not appear to have been any significant increase in collateral attack proceedings since the Second Circuit's decision in Stephenson was issued and left in place by the divided Court'); Woolley, supra note 3, at 443 ("Notwithstanding the longstanding availability of collateral attack, such attacks have not been common, suggesting that there is no basis for alarmist predictions."). For an explanation of why one would expect collateral attacks to be relatively rare, see Koniak, supra note 3, at 1858 (noting that "the chance of persuading ... another trial[] court . . . to say that the first court erred is exceedingly slim" because "[t]rial judges are naturally, and in most cases appropriately, reluctant to hold that another trial judge made such an error").

242. In so concluding, I assume that Congress has power to authorize federal courts to exercise personal jurisdiction over all class members who have minimum contacts with the nation. See supra Part III.C.5.

243. Professors Issacharoff and Nagareda have argued that certain fora cannot be trusted to properly litigate a collateral attack:

Just as the array of potential fora invites proponents of collusive class settlements to seek the anomalous approving forum, the same array invites those hostile to the deal to seek 
Congress likely has authority under Article III to permit removal to federal court of a suit premised on inadequate representation of an absent class member. ${ }^{244}$

The cure offered by the American Law Institute is in any event worse than the supposed malady. The Institute-and Professors Issacharoff and Nagareda - seem determined to sharply limit the ability of an absent class member to challenge even settlements that all concerned should have recognized were unreasonable. ${ }^{245}$ But neither the benefits of finality with respect to class judgments nor the possible misuse of collateral attack can justify a standard that would immunize from collateral attack class judgments that are manifestly unfair to absent class members who have relied on the promise of adequate representation. Aggregate Litigation has many virtues, but its cramped understanding of the adequate-representation requirement and its effort to severely restrict the availability of collateral attack should be soundly rejected.

the forum anomalously inclined to allow the collateral challenger some extraordinary gain by threatening to blow up the entire settlement. The stock in trade for this maneuver is to claim inadequate class representation and thereby to deny preclusive effect to the deal. ...

The problem, then, is that the search for an anomalous forum might allow collateral attacks on class settlements to bust not only bad class judgments, but also good ones.

Issacharoff \& Nagareda, supra note 6, at 1669-70. But see Struve, supra note 90, at 2144 (noting that Professors Issacharoff and Nagareda present no evidence that anomalous state courts are a problem with respect to collateral attack). The Class Action Fairness Act ("CAFA") sought to address the problem of the anomalous court with respect to certification by permitting defendants to easily remove a case from state to federal court. Pub. L. No. 109-2, 119 Stat. 4 (codified as amended in scattered sections of 28 U.S.C.); see also Issacharoff \& Nagareda, supra note 6, at 1665 ("CAFA expands the diversity jurisdiction of the federal courts to turn this phenomenon on its head, effectively enabling the defendant, if she wishes, to use a change of forum to empower the negatives on the class certification question to trump the anomalous positive."). Because CAFA permits only a defendant to remove, it does not prevent a defendant and class counsel from seeking the approval of a collusive settlement by an anomalous state court. Issacharoff \& Nagareda, supra note 6, at 1666-67 (citing 28 U.S.C. § 1453(b) (2005)); Wolff, supra note 215, at 2126.

244. See Mesa v. California, 489 U.S. 121, 136 (1989) (noting in the context of the federal officer removal statute, 28 U.S.C. 1442(a)(1), that "it is the raising of a federal question in the officer's removal petition that constitutes the federal law under which the action against the federal officer arises for Article III purposes"); see also Michael G. Collins, The Unhappy History of Federal Question Removal, 71 IOWA L. REV. 717, 718 (1986) ("[I]n a long line of decisions, the Supreme Court held that a federal defense made a case 'arise under' federal law within the meaning of both article III" and the general removal provision of the now-defunct Judiciary Act of 1875.). As previously noted, a collateral attack on a class judgment can often be conceptualized as an affirmative defense to the affirmative defense of preclusion asserted by the defendant. See supra notes $151-53$ and accompanying text.

245. See supra Part II.C.3-5 (discussing the Agent Orange, BancBoston, and Epstein settlements). 